Article

\title{
Hybrid Materials Based on L,D-Poly(lactic acid) and Single-Walled Carbon Nanotubes as Flexible Substrate for Organic Devices ${ }^{\dagger}$
}

\author{
Patryk Fryń ${ }^{1}{ }^{(D)}$, Krzysztof Artur Bogdanowicz ${ }^{2}{ }^{\circledR}$, Natalia Górska ${ }^{3}$, Jakub Rysz ${ }^{1}{ }^{(D}$, \\ Piotr Krysiak ${ }^{2}$, Mateusz Marzec ${ }^{4}$ (D), Monika Marzec 1,*D, Agnieszka Iwan ${ }^{5, *(D)}$ \\ and Adam Januszko ${ }^{5}$ \\ 1 Institute of Physics, Jagiellonian University, Prof. S. Lojasiewicza 11, 30-348 Krakow, Poland; \\ patryk.fryn@doctoral.uj.edu.pl (P.F.); jakub.rysz@uj.edu.pl (J.R.) \\ 2 Military Institute of Engineer Technology, Obornicka 136 Str., 50-961 Wroclaw, Poland; \\ bogdanowicz@witi.wroc.pl (K.A.B.); krysiak@witi.wroc.pl (P.K.) \\ 3 Faculty of Chemistry, Jagiellonian University, Gronostajowa 2, 30-387 Kraków, Poland; \\ gorska@chemia.uj.edu.pl \\ 4 Academic Centre for Materials and Nanotechnology, AGH University of Science and Technology, \\ Av. Mickiewicza 30, 30-059 Krakow, Poland; marzecm@agh.edu.pl \\ 5 Faculty of Security and Safety Research, General Tadeusz Kosciuszko Military University of Land Forces, \\ Wroclaw, MULF Wroclaw, Czajkowskiego 109 Str., 51-147 Wroclaw, Poland; adam.januszko@awl.edu.pl \\ * Correspondence: monika.marzec@uj.edu.pl (M.M.); agnieszka.iwan@awl.edu.pl (A.I.) \\ + In memory of Dr. Eng. Piotr Dacko.
}

Received: 9 October 2018; Accepted: 8 November 2018; Published: 15 November 2018

check for updates

\begin{abstract}
We report on the application of L,D-poly(lactic acid) (L,D-PLA) with dispersed Single-Walled Carbon Nanotubes (SWCN) as a flexible translucent electrode for organic devices. We used commercially available nanotubes in various weight ratios from 0 to $8 \%$ dispersed in chloroform polymeric solution by ultrasonication and were drop cast. The created hybrid materials were investigated by differential scanning calorimetry to determine the influence of SWCN content on the thermal behavior, while polarizing optical microscope was used to find the effect of mechanical deformations on the textures. Drop-cast films were studied by optical transmittance, conductivity, dielectric properties and by thermal imaging under applied potential. Thermal imaging provided evidence of visible voltage-activated conduction. Simple mechanical deformation such as bending with stretching at edge to ca. 90 and elongation test were performed. Moreover, interactions between L,D-poly(lactic acid) and SWCN were investigated by FT-IR and NMR spectroscopy. Finally, we can conclude that the thermographic examination of created films permits fast, simple and inexpensive localization of defects on the surface of L,D-PLA:SWCN film, together with the electrical properties of the films.
\end{abstract}

Keywords: L,D-poly(lactic acid); single wall carbon nanotubes; thermographic camera; hybrid materials; flexible substrate

\section{Introduction}

Organic devices, such as organic solar cells, for example, are mainly constructed on a glass substrate [1-16]. However, organic solar cells on flexible substrates have also been investigated for potential use in our life [17-32]. Up to now, only few reports have been dedicated to flexible organic solar cells, because of the still low power conversion efficiency (PCE) value in comparison with organic solar cells built on glass substrates [17-22,33]. Our literature search showed that, as a substrate in 
organic (polymer) solar cells, predominantly polyethyleneterephthalate (PET) has been tested, and the highest PCE value was observed to be approximately $4.2 \%$ [16,34]. Moreover, other polymers such as polyethylene naphthalene [23,25] and polyethersulfone [31] have been tested as a flexible substrate in polymer solar cells with ITO or graphene as an electrode, giving similar results.

In our last study we investigated Ecoflex ${ }^{\circledR}$ as a substrate covered with graphene oxide for application in organic solar cells [35], and this inspired us to think about the possibility of applying poly(lactic acid) (PLA), widely known as biodegradable material [36], in organic devices. It is well known that due to the chiral nature of lactic acid, several distinct forms of polylactide exist, such as L-PLA, D-PLA, and L,D-PLA which exhibit different properties, especially with regard to melting temperature and crystallinity [37,38]. Strange et al. [39] investigated L-PLA in polymer solar cells as a substrate loaded with nanoclay in an attempt to improve the thermal properties and reduce permeation of water and oxygen. As an alternative, the usage of a new biodegradable polymer electrolyte was proposed for a Dye Sensitized Solar Cell (DSSC); a biopolymer containing about 2-3\% starch (20 to $25 \%$ amylose and 75 to $80 \%$ amylopectin) called Arrowroot (Maranta arundinacea) was applied [40]. On the other hand, Zhou et al. [41] investigated recyclable organic solar cells on cellulose nanocrystal substrates.

However, with respect to biodegradable, flexible organic solar cells, not only is an adequate substrate required, but also nanomaterials that provide suitable electrical properties, such as work function or resistivity. Presently, instead of indium tin oxide (ITO) graphene, Ag, or carbon nanotubes are mainly proposed as electrode [5]. It is well known, that ITO on flexible substrates like PET and polyimide possesses good optical and electrical properties. However such ITO possesses disadvantages, such as: (i) the limited annual production of indium, as a rare metal, causes an increase in ITO prices; (ii) ITO is brittle and cannot withstand mechanical deformation; and (iii) degradation of ITO in organic solar cells is caused by PEDOT:PSS used as hole transporting layer, eliminating its wide, cheap and long-term application. Therefore, finding substitutes to ITO is of great significance in organic devices [42].

Both single-walled carbon nanotubes (SWCN) and multi-walled carbon nanotubes (MWCN) have been widely investigated since 2004 as transparent conductive films in organic devices, and they have shown promising applicability in optoelectronic devices and as solar cells, organic light-emitting diodes (OLEDs) and touch panels [42,43].

Carbon nanotubes $(\mathrm{CN})$, among numerous diverse applications, can be used as an electrode in organic solar cells on flexible substrates; exemplary configurations of flexible substrate and electrode can be named: PET/CN, or PET/poly(aniline):CN [42]. Moreover, Calogero et al. [44] proposed SWCN deposition on stainless-steel sheet substrates as novel counter electrodes for ruthenium polypyridine-based DSSC.

An interesting application of $\mathrm{CN}$ was proposed by Husmann and Zarbin, in which multifunctional carbon nanotubes/ruthenium purple thin films were tested as sensors and electrochromic materials [45].

Additionally, the creation of a suitable composition of polymers, as well as the interactions between both compounds, is not trivial for the excellent applicability of carbon nanotubes. For example, hydrogen-bonded metallo-supramolecular polymers based on ruthenium or iron complexes for the selective extraction of SWCN were investigated by Oka et al. [46].

Noteworthy work was done by Ma et al. [47] in which a novel route was proposed to fabricate entirely bio-based conductive nanocomposites with a low percolation threshold of conductivity and enhanced crystallization and mechanical performance. To achieve this goal, the authors proposed using poly(D-lactide)/poly(hydroxyalkanoate) (PDLA/PHA) nanocomposites with multiwalled carbon nanotubes (MWCNTs) and MWCNTs-g-PLLA (prepared via ring opening polymerization of L-lactide with grafting degree of $17 \%$ ).

Instead of carbon nanotubes, graphene has also been applied in PLA compositions. For example, Lei et al. [48] prepared conductive PLA with poly(methyl methacrylate) (PMMA) functionalized 
graphene by admicellar polymerization. Moreover, Zhang et al. [49] investigated a series of transparent PLA nanocomposite films incorporated with fully exfoliated octadecylamine-functionalized graphene as an effective nanofiller. On the other hand, Cui et al. [50] studied highly heat-resistant PLA-based foam with low foam density and excellent electromagnetic interference shielding performance fabricated using the nonsolvent-induced phase-separation and freeze-drying method.

All scientists agree that taking into account the possible applications of flexible organic devices in our lives is still a challenge. One of the challenges is the construction of efficient devices with long-term stability. To solve this problem, each layer in the device should be optimized. On the other hand, considering organic devices as ecologically friendly devices according to Green Chemistry concepts, new flexible and translucent substrates based on biodegradable components are necessary.

Therefore, in this study, we propose hybrid, biodegradable thin films based on Single-Wall Carbon Nanotubes (SWCN) and L,D-poly(lactic acid) (PLA) as biodegradable polymer. We report the influence of the amount of SWCN and mechanical deformation on the electrical and thermal behavior of L,D-PLA. We paid a lot of attention to investigating L,D-PLA/SWCN interactions using FT-IR and NMR methods, with a view towards applications in organic biodegradable devices.

It is known that organic devices could work for industrial applications, such as solar panel. One of the main problems in solar panels is the presence of various mechanical and structural defects that cause a decrease in power generation. To analyze defects in solar cells, various techniques have been used; however, thermal imaging is a fast and simple method for identifying and locating defects. Therefore, one of the main goals of this work was to analyze defects in the produced flexible L,D-PLA:SWCN films via thermal imaging.

\section{Experimental}

\subsection{Materials}

The chemicals and reagents were used as received from Sigma-Aldrich (St. Louis, MO, USA). The Single-Walled Carbon Nanotubes (SWCN, Sigma-Aldrich, St. Louis, MO, USA) used have average diameter $0.84 \mathrm{~nm}$, median length $1 \mu \mathrm{m}, \geq 95 \%$ carbon basis ( $\geq 99 \%$ as carbon nanotubes). L,D-PLA was received from GALACTIC. (Brussels, Belgium). Chloroform 98.5\% PURE P.A.-BASIC (POCH S.A).

L,D-PLA: ${ }^{1} \mathrm{H}$ NMR $\left(400 \mathrm{MHz}, \mathrm{CDCl}_{3}\right), \delta[\mathrm{ppm}]: 5.1(\mathrm{~m}, 1 \mathrm{H},-(\mathrm{C}=\mathrm{O})-\mathrm{CH}<), 1.5(\mathrm{~m}, 3 \mathrm{H}$, $\left.>\mathrm{CH}-\mathrm{CH}_{3}\right) .{ }^{13} \mathrm{C} \mathrm{NMR}\left(100 \mathrm{MHz}, \mathrm{CDCl}_{3}\right), \delta$ [ppm]: 169.7 (aliphatic carboxyl, $\left.-(\mathrm{C}=\mathrm{O})-\right), 69.1$ (methyline, $-(\mathrm{C}=\mathrm{O})-\mathrm{CH}<), 16.7$ (methyl, $>\mathrm{CH}-\mathrm{CH}_{3}$ ). The L, D-PLA were characterized by ${ }^{1} \mathrm{H}-{ }^{13} \mathrm{C}$ HMQC (see Figure 1). Approximate number of repetitive units $=101$. Approximate average molecular mass $=7274 \mathrm{~g} / \mathrm{mol}$.

FT-IR: $2995 \mathrm{~m} \mathrm{v}$ as $\left(\mathrm{CH}_{3}\right), 2965 \mathrm{sh} v\left(\mathrm{CH}_{3}\right), 2944 \mathrm{~m}$ vs $\left(\mathrm{CH}_{3}\right), 2879 \mathrm{w}, 2861 \mathrm{w}, 1748 \mathrm{~s} v(\mathrm{C}=\mathrm{O}), 1722 \mathrm{sh}$, $1453 \mathrm{~m} \mathrm{\delta}_{\text {as }}\left(\mathrm{CH}_{3}\right), 1382 \mathrm{~m}_{\mathrm{s}}\left(\mathrm{CH}_{3}\right), 1360 \mathrm{~m} \delta_{\mathrm{s}}\left(\mathrm{CH}_{3}\right), 1302 \mathrm{w}, \mathrm{br} \delta(\mathrm{CH}), 1268 \mathrm{~m} \mathrm{v}(\mathrm{C}-\mathrm{O}), 1209 \mathrm{sh}, 1180 \mathrm{~s}$ $v_{\mathrm{s}}(\mathrm{C}-\mathrm{O}-\mathrm{C}), 1127 \mathrm{~s} v(\mathrm{C}-\mathrm{O}), 1081 \mathrm{~s} v_{\text {as }}(\mathrm{C}-\mathrm{O}-\mathrm{C}), 1043 \mathrm{~s} v(\mathrm{C}-\mathrm{O}), 1020 \mathrm{sh}, 956 \mathrm{w}, 919 \mathrm{w}, 896 \mathrm{w}, 869 \mathrm{~m}$ $v(\mathrm{C}-\mathrm{C}), 847 \mathrm{sh}, 754 \mathrm{~m} v(\mathrm{C}-\mathrm{C}), 735 \mathrm{sh}, 706 \mathrm{br}, 669,394 \mathrm{~m} \mathrm{~cm}^{-1}$ (s-strong, m-medium, w-weak, br-broad, sh-shoulder). 


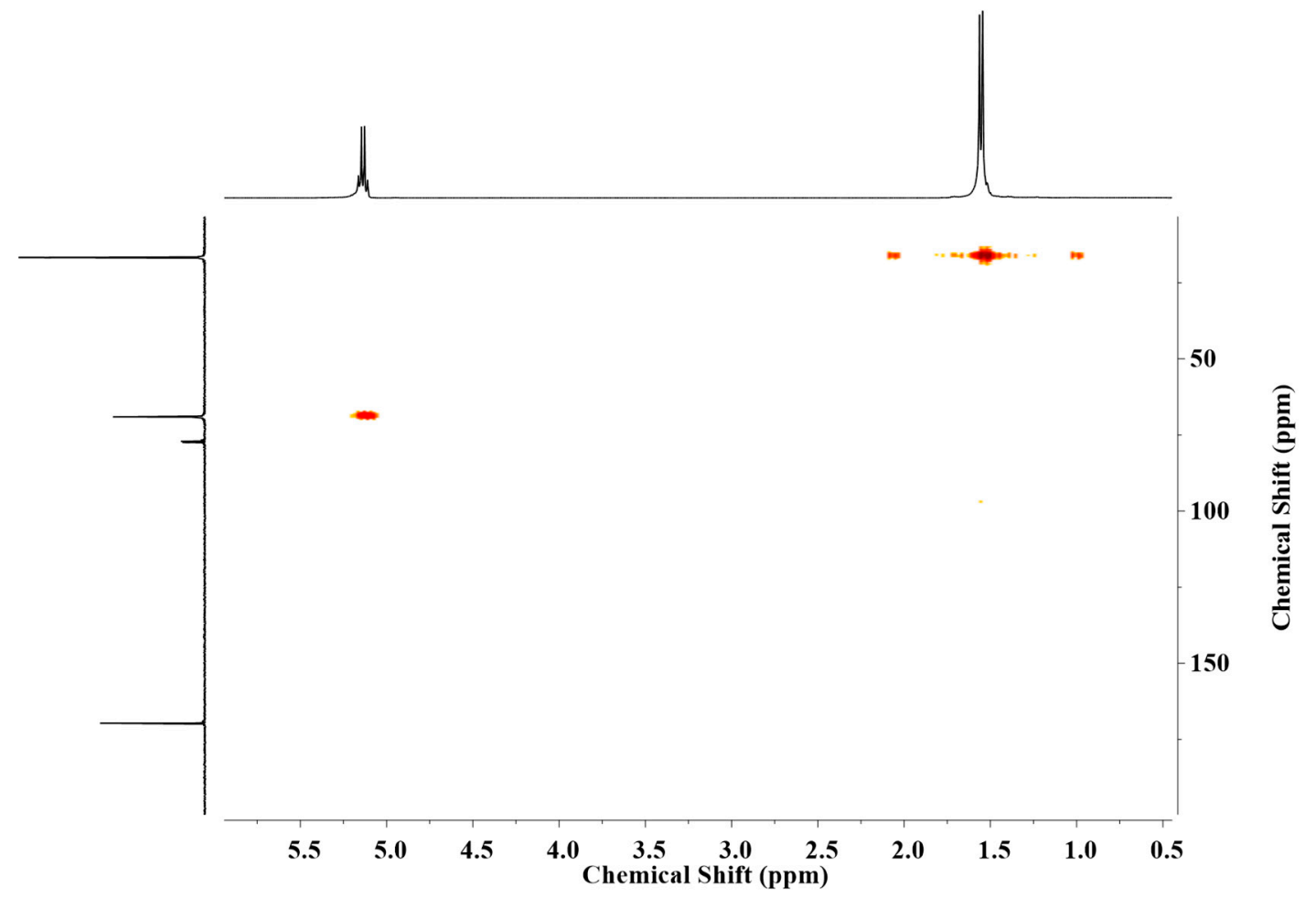

Figure $1 .{ }^{1} \mathrm{H}-{ }^{13} \mathrm{C}$ NMR (HMQC) spectra for L,D-PLA.

Preparation of L,D-PLA:SWCN Hybrid Materials

To prepare the mixture of L,D-PLA with SWCN, the appropriate amounts of L,D-PLA and SWCN were mixed in chloroform to obtain a solution. The solution was stirred on the magnetic stirrer for $1 \mathrm{~h}$, and then sonification $(60 \%)$ was performed for different durations depending on the concentration: L,D-PLA $/ 0.01 \%$ SWCN, L,D-PLA / $0.1 \%$ SWCN and L,D-PLA $/ 1 \%$ SWCN (80 cycles) while L,D-PLA /5\% SWCN and L,D-PLA $/ 8 \%$ SWCN (40 cycles); 1 cycle $=30 \mathrm{~s}$ sonification $+30 \mathrm{~s}$ interruption. The L,D-PLA mixed with chloroform was only stirred on the magnetic stirrer for $1 \mathrm{~h}$, without sonification after that. All the solutions were then poured into $8 \mathrm{~cm}$ glass Petri dishes and kept at room temperature for $12 \mathrm{~h}$ to evaporate the chloroform. After that time, the samples had the form of thin flexible layers $(8 \mathrm{~cm}$ diameter), and easily detached from the bottom of the Petri dishes. The thickness of the samples was measured by the profilometric method.

\subsection{Characterization Methods}

DSC measurements were done by using differential scanning calorimeter Perkin Elmer Diamond 8000. Samples of ca. $10 \mathrm{mg}$ were placed in aluminum crucibles and firmly closed with a press. The measurements were carried out both for heating and cooling at a rate equal to $5{ }^{\circ} \mathrm{C} / \mathrm{min}$.

Texture observations were done using a Nikon Eclipse LV100 POL polarizing microscope (NIKON Inc., Tokyo, Japan). The images were registered in transmitted light ( $90^{\circ}$ crossed polarized) by a computer-controlled camera at room temperature. The samples were placed between two glass plates.

Mechanical deformation was carried out by bending and stretching samples on an edge of ca. $90^{\circ}$. The procedure was repeated twenty times for each side of the sample.

Tensile mechanical properties were measured using a testing machine Instron 33R4469 (Instron, Norwood, MA, USA) with a load cell of $5 \mathrm{kN}$ with software Bluehill 3.0. Samples were in a form of thin strips and uniform width of $10 \mathrm{~mm}$. Samples were tested at room temperature at a crosshead speed of $10 \mathrm{~mm} / \mathrm{min}$.

Resistivity $\mathrm{R}$ was measured at twenty different places on the samples using the four point method, by using a Source Meter Keithley 2400 (KEITHLEY, Cleveland, OH, USA). 
The thickness of the analyzed samples was determined using DektakXT (Bruker Co., Billerica, MA, USA) Stylus profilometer working in N-Lite mode, which ensures very low stylus load (radius $2 \mu \mathrm{m}$, load $0.3 \mathrm{mg}$ ) on the sample surface, ensuring non-destructive analysis. The edge of each sample was measured, and the edge type function was fitted to the obtained data. A schematic illustration of the acquired data and function fitted for L,D-PLA with $1 \%$ SWCN is depicted in Figure 2. The sample thickness for SWCN concentrations equal to $0.1 \%, 1 \%, 5 \%$ and $8 \%$ are presented in Table 1 . The remaining thicknesses of the samples were equal to 29.1 and $282.1 \mu \mathrm{m}$ for L,D-PLA from chloroform and the $0.01 \%$ SWCN mixture, respectively.

Table 1. Resistivity $(R)$, conductivity $(\sigma)$ and thickness $(d)$ of L,D-PLA with selected content of SWCN.

\begin{tabular}{cccccc}
\hline $\begin{array}{c}\text { Amount of } \\
\text { SWCN }\end{array}$ & $\begin{array}{c}\mathbf{R}[\Omega] \\
\text { before } \\
\text { Deformation }\end{array}$ & $\begin{array}{c}\mathbf{R}[\Omega] \\
\text { after Deformation }\end{array}$ & $\boldsymbol{d}[\mu \mathrm{m}]$ & $\begin{array}{c}\sigma[\mathrm{S} / \mathrm{m}] \\
\text { before } \\
\text { Deformation }\end{array}$ & $\begin{array}{c}\sigma[\mathrm{S} / \mathrm{m}] \\
\text { after Deformation }\end{array}$ \\
\hline $0.1 \%$ & $(2.14 \pm 0.45) \times 10^{3}$ & $(2.50 \pm 0.68) \times 10^{3}$ & 196.9 & $(5.2 \pm 1.1) \times 10^{-1}$ & $(4.5 \pm 1.2) \times 10^{-1}$ \\
\hline $1 \%$ & $(1.12 \pm 0.25) \times 10$ & $(1.90 \pm 0.33) \times 10$ & 207.6 & $(9.5 \pm 2.1) \times 10$ & $(5.59 \pm 0.98) \times 10$ \\
\hline $5 \%$ & $1.99 \pm 0.22$ & $2.365 \pm 0.086$ & 109.6 & $(1.01 \pm 0.11) \times 10^{3}$ & $(8.51 \pm 0.31) \times 10^{2}$ \\
\hline $8 \%$ & $7.3 \pm 1.6$ & $8.43 \pm 0.85$ & 51.8 & $(5.8 \pm 1.2) \times 10^{2}$ & $(5.06 \pm 0.51) \times 10^{2}$ \\
\hline
\end{tabular}

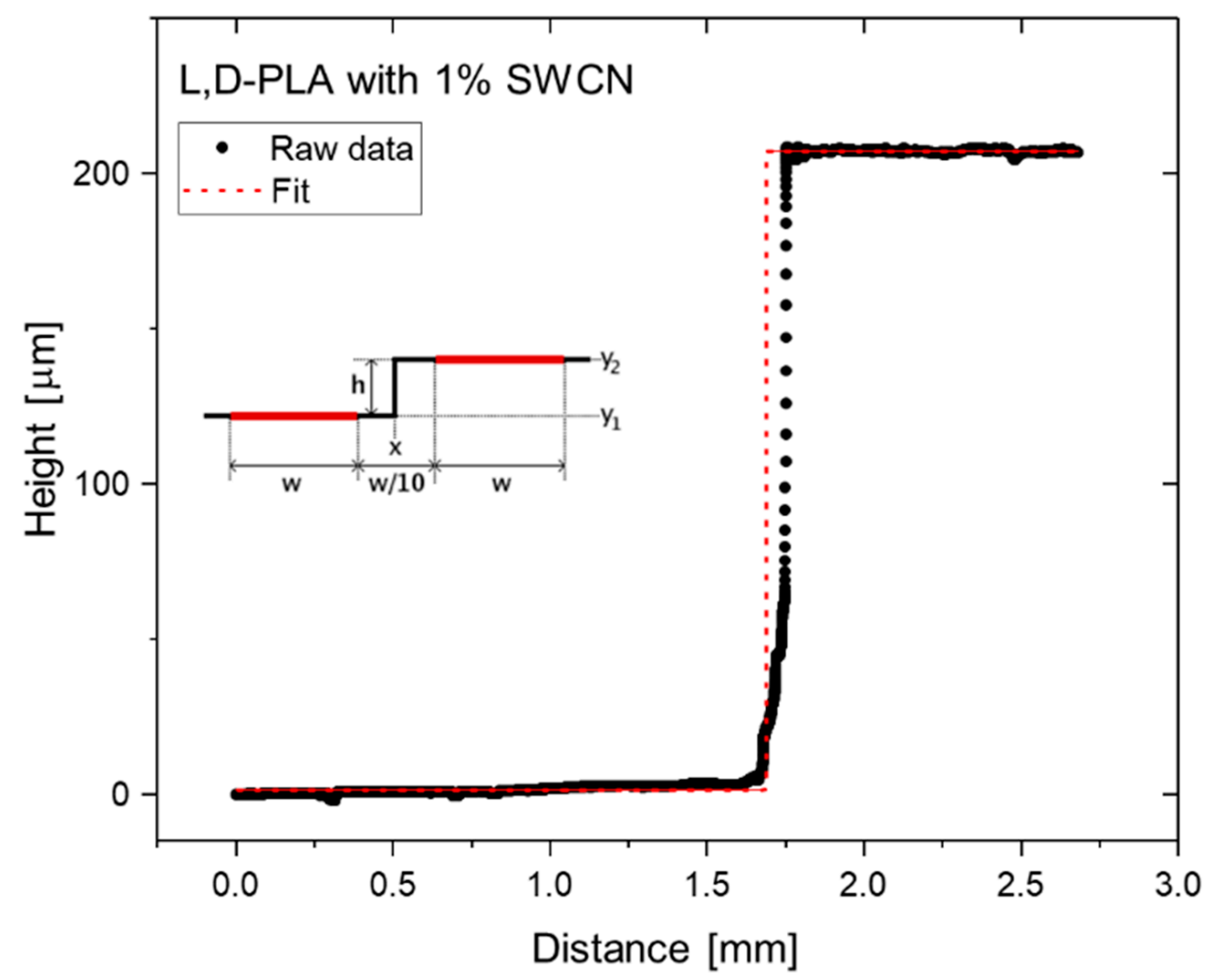

Figure 2. Topography profile (dots) obtained from profilometer measurements used for the determination of L,D-PLA with the $1 \%$ SWCN sample thickness by fitting edge function (dashed line): $\mathrm{y}_{1}$ and $\mathrm{y}_{2}$ are baselines, and $\mathrm{h}$ is the resultant thickness.

Dielectric measurements at room temperature were performed by using Novocontrol Alpha Spectrometer in the frequency range $0.1 \mathrm{~Hz}-10 \mathrm{MHz}$ at a measuring oscillation voltage of $0.5 \mathrm{~V}$. The samples, in the form of circle $2 \mathrm{~cm}$ in diameter, were placed between the two electrodes.

Thermal behavior was observed using a thermographic camera (VIGOcam v50, VIGO System S.A, Ozarów Mazowiecki, Poland) while applying voltage bias of between 0 and $32 \mathrm{~V}$ using a conventional DC source (Regulated Power Supply PWR 400L (KIKUSUI)). 
NMR results were recorded on a Jeol ECZ-400 S $400 \mathrm{MHz}$ with a delay time of $5 \mathrm{~s}$. Deuterated chloroform $\left(\mathrm{CDCl}_{3}\right)$ was used as solvent. Measurements were carried out at room temperature on $10-15 \%(w / v)$ sample solutions. Heteronuclear multiple quantum correlation (HMQC) experiments were performed according to standard procedures.

ATR FT-IR spectra were collected using an ALPHA Bruker spectrometer equipped with a 1-reflection ATR diamond crystal (Bruker Co., Billerica, MA, USA). Spectra were collected at room temperature in the range of $4000-500 \mathrm{~cm}^{-1}$, with a spectral resolution of $4 \mathrm{~cm}^{-1}$ and at 32 scans per spectrum. All spectrum processing was performed using Bruker OPUS software (Version 7.0).

The optical properties of polymer samples modified with carbon nanotubes in the range from $400 \mathrm{~nm}$ to $900 \mathrm{~nm}$ were characterized using a home-built system based on the spectrometer USB2000 with linear CCD detector (OceanOptics Ltd., Largo, FL, USA) controlled by SpectralSuite software. Light from a halogen lamp directed on the studied film and the transmitted signal were registered by the spectrometer, and the absorbance spectrum was calculated based on the previously stored reference spectrum of the lamp. The reflection signal was collected using a fiberoptic reflection probe (OcenOptics, Largo, FL, USA).

\section{Results and Discussion}

The L,D-PLA was mixed with SWCN in different ratios and drop-cast on glass substrate to create a flexible layer after chloroform evaporation. In Figure $3 \mathrm{a}, \mathrm{b}$ photos of the created films are presented to show their transparency and flexibility, along with the increase in the amount of SWCN. Figure 3c presents the absorbance spectra of pure L,D-PLA and two films admixed with $0.01 \%$ and $0.1 \%$ of SWCN. Unfortunately, for high concentrations, no light is transmitted through the film. The reflection spectra of all prepared samples are presented in Figure 3d. The absorbance of the polymer films admixed with single-walled carbon nanotubes increases rapidly with their concentration so that films containing $1 \%$ SWCN become non-transparent. The shape of the absorption spectrum of the film with $0.1 \%$ of SWCN corresponds to the absorption spectrum of SWCN in solution. The most pronounced maximum, at c.a. $640 \mathrm{~nm}$, corresponds to absorption of SWCN with chirality $(7,6)$. The other two absorption bands at c.a. 720 and $500 \mathrm{~nm}$ correspond to SWCN with chirality $(8,7)$ and $(7,3)$, respectively. The reflectance of the films declines with SWCN content from less than $10 \%$ for polymer film to less than 2 for film admixed with $8 \%$ SWCN, which also indicates the high absorption of light into the film.

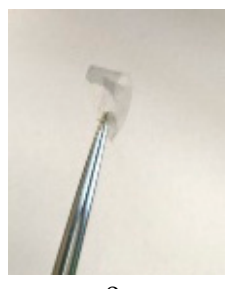

0

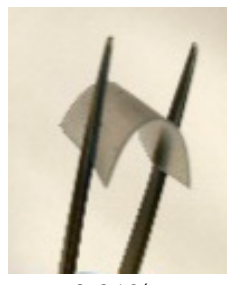

$0.01 \%$

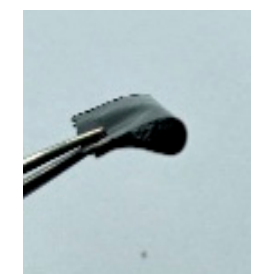

$0.1 \%$

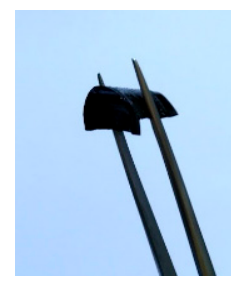

$1 \%$

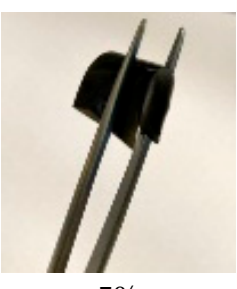

$5 \%$

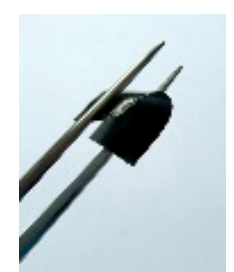

$8 \%$ SWCN

(a)

Figure 3. Cont. 


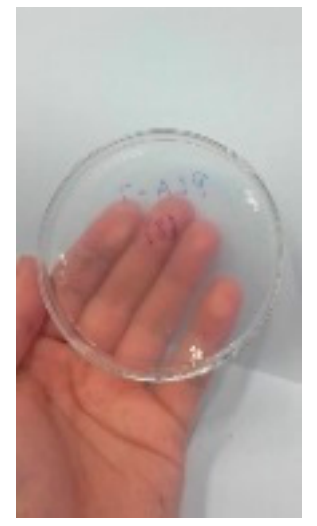

$0 \%$

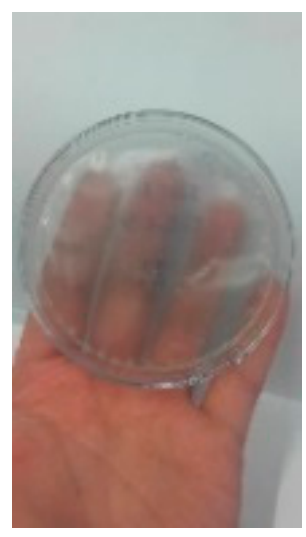

0.01

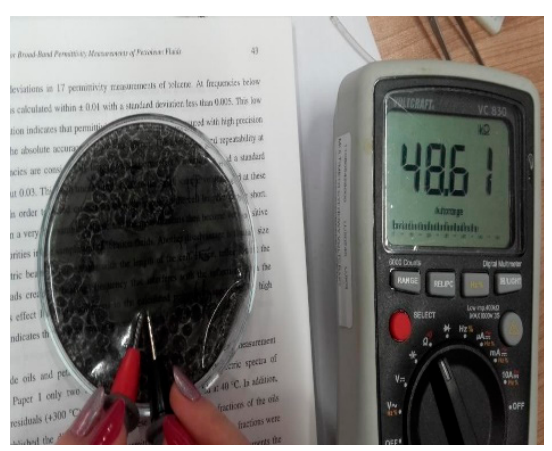

$0.1 \%$ SWCN

(b)
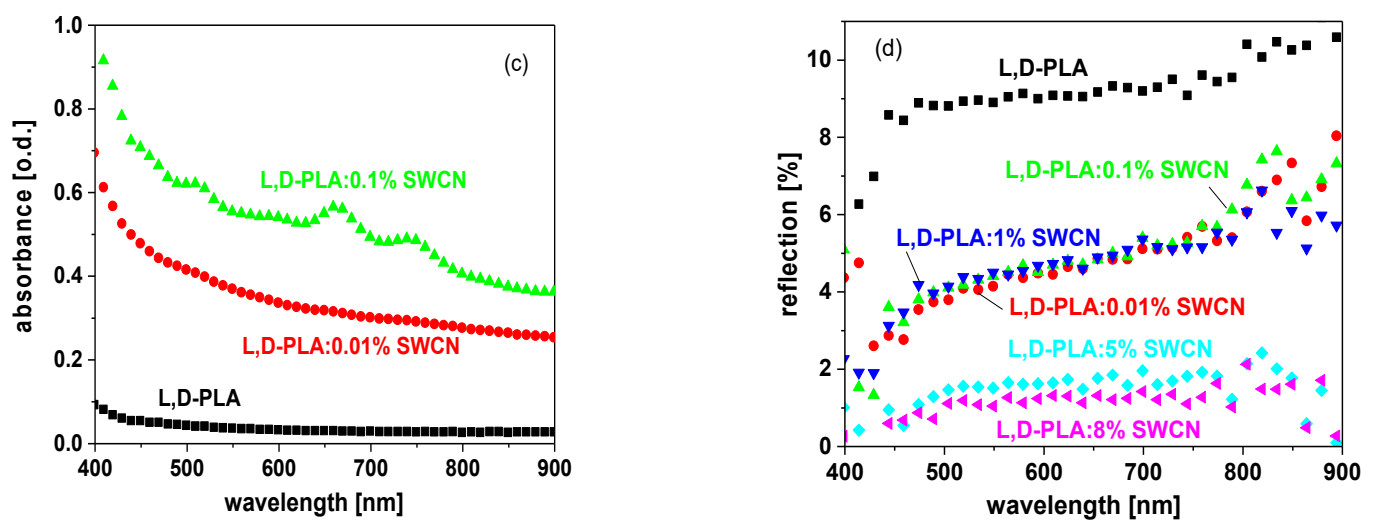

Figure 3. (a) Created L,D-PLA films without and with SWCN content of $0.01 \%, 0.1 \%, 1 \%, 5 \%, 8 \%$, (b) translucence of L,D-PLA films without and with SWCN content of $0.01 \%$, and $0.1 \%$, (c) absorbance and (d) reflection UV-Vis spectra.

\subsection{DSC Measurements and Texture Observations before and after Mechanical Deformation}

L,D-PLA and its mixtures with SWCN (different concentrations) were studied using the DSC method to determine the influence of content of SWCN on the thermal behavior. Three cycles of heating and cooling were done for each sample, and the obtained results were repeatable. The DSC curves registered upon heating and cooling at a rate of $5^{\circ} \mathrm{C} / \mathrm{min}$ are presented in Figure $4 \mathrm{a}, \mathrm{b}$, respectively. DSC measurements show that the SWCN content has no significant influence on the phase transitions. According to the literature [51], the peak registered upon heating at ca. $150{ }^{\circ} \mathrm{C}$ is connected with melting ( $\Delta H$ ca. $19-20 \mathrm{~J} / \mathrm{g}$, calculated as the sum of two peaks registered close to each other), while the peak at around $55^{\circ} \mathrm{C}$ was registered at both heating and cooling as a glass-transition $(\Delta H \mathrm{ca} .1-1.5 \mathrm{~J} / \mathrm{g})$. In turn, the exothermic anomaly visible at ca. $100{ }^{\circ} \mathrm{C}$ during heating is related to chloroform (solvent used during preparation of the mixtures). In this case, enthalpy changes depending strongly on concentration of SWCN, and is equal to $-10.6 \mathrm{~J} / \mathrm{g}$ (L,D-PLA), $-21.1 \mathrm{~J} / \mathrm{g}(0.01 \% \mathrm{SWCN}),-7.0 \mathrm{~J} / \mathrm{g}$ $(0.1 \% \mathrm{SWCN}),-17.6 \mathrm{~J} / \mathrm{g}(1 \% \mathrm{SWCN}),-18.0 \mathrm{~J} / \mathrm{g}(5 \% \mathrm{SWCN})$ and $-12.8(8 \% \mathrm{SWCN})$, which means that chloroform still exists in different volumes in the structure of the obtained layers. This peak was not observed for pure L,D-PLA as a solid (Figure 4a) or for L,D-PLA prepared from the solution in methylene chloride, while it appeared for L,D-PLA prepared from the solution in chloroform (Figure 4a). 

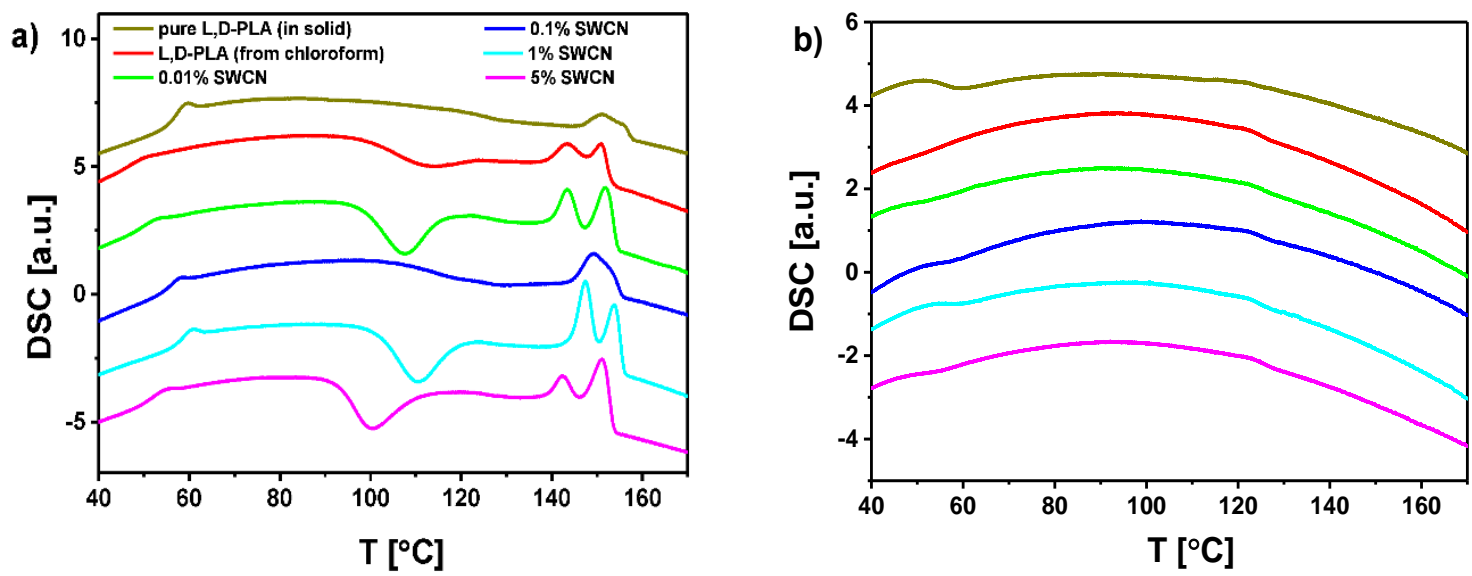

Figure 4. DSC curves registered for L,D-PLA and its mixtures with SWCN on heating (a) and cooling (b) at a rate of $5^{\circ} \mathrm{C} / \mathrm{min}$.

To define the possible applicability of L,D-PLA in organic devices, the obtained hybrid films were investigated by optical microscopy and thermographic camera before and after mechanical deformation. To simulate mechanical damage, samples were bent and stretched 20 times, where half of the sample was placed and held on the edge of a rigid flat surface, and the other half was suspended in air. Next, a force was used to bend the sample to the side of the support, as depicted in Figure 5.

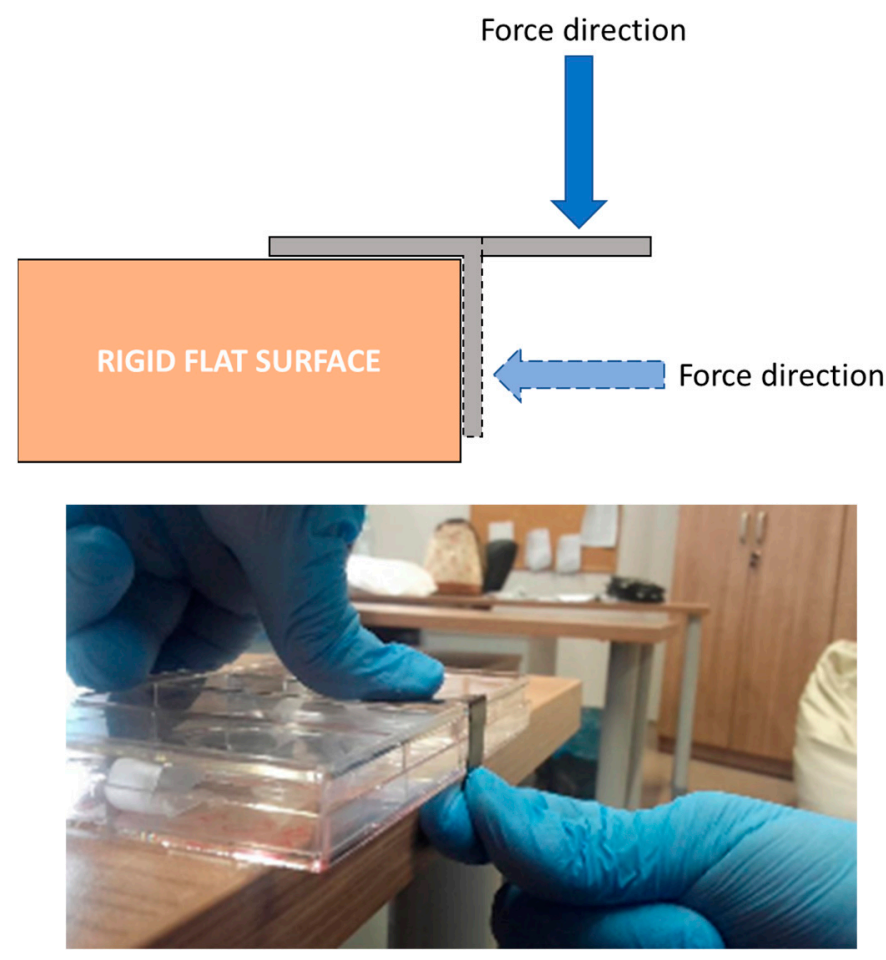

Figure 5. Schematic representation of simple preliminary mechanical deformation procedure together with photo of deformation of L,D-PLA film with SWCN.

Optical textures under polarizing microscope $\left(90^{\circ}\right.$ crossed polarizers) in transmitted light were analyzed for L,D-PLA and hybrid samples with SWCN concentrations equal to $0.01 \%$ and $0.1 \%$ before and after mechanical deformations, whereas samples with concentration of $1 \%, 5 \%$ and $8 \%$ SWCN were opaque for white light-they are completely black. Textures registered at room temperature for pure L,D-PLA and the three mixtures before and after mechanical deformations are presented in Figure 6. The effect of mechanical deformation is clearly visible for all studied samples. For pure 
L,D-PLA after deformation, the structure and texture, as well as the color, were changed, which means that internal stress had occurred. For the sample with a concentration of $0.1 \% \mathrm{SWCN}$, the color did not change, but numerous micro-cracks appeared, which is clearly visible on the enlarged texture in Figure 6. The orientation of the micro-cracks is parallel to the edge on which the bending and stretching took place. On the other hand, for the SWCN concentration of $0.01 \%$, the changes in texture are between that for pure L,D-PLA and its mixture with $0.1 \%$ SWCN content (a slight change in color and micro-cracks appear). When increasing the concentration of SWCN in the sample, the amount of micro-cracks increases, internal stress diminishes (change in the texture color vanishes) and stretching was able to damage the sample. This suggests that the presence of SWCN stiffens the structure of L,D-PLA.

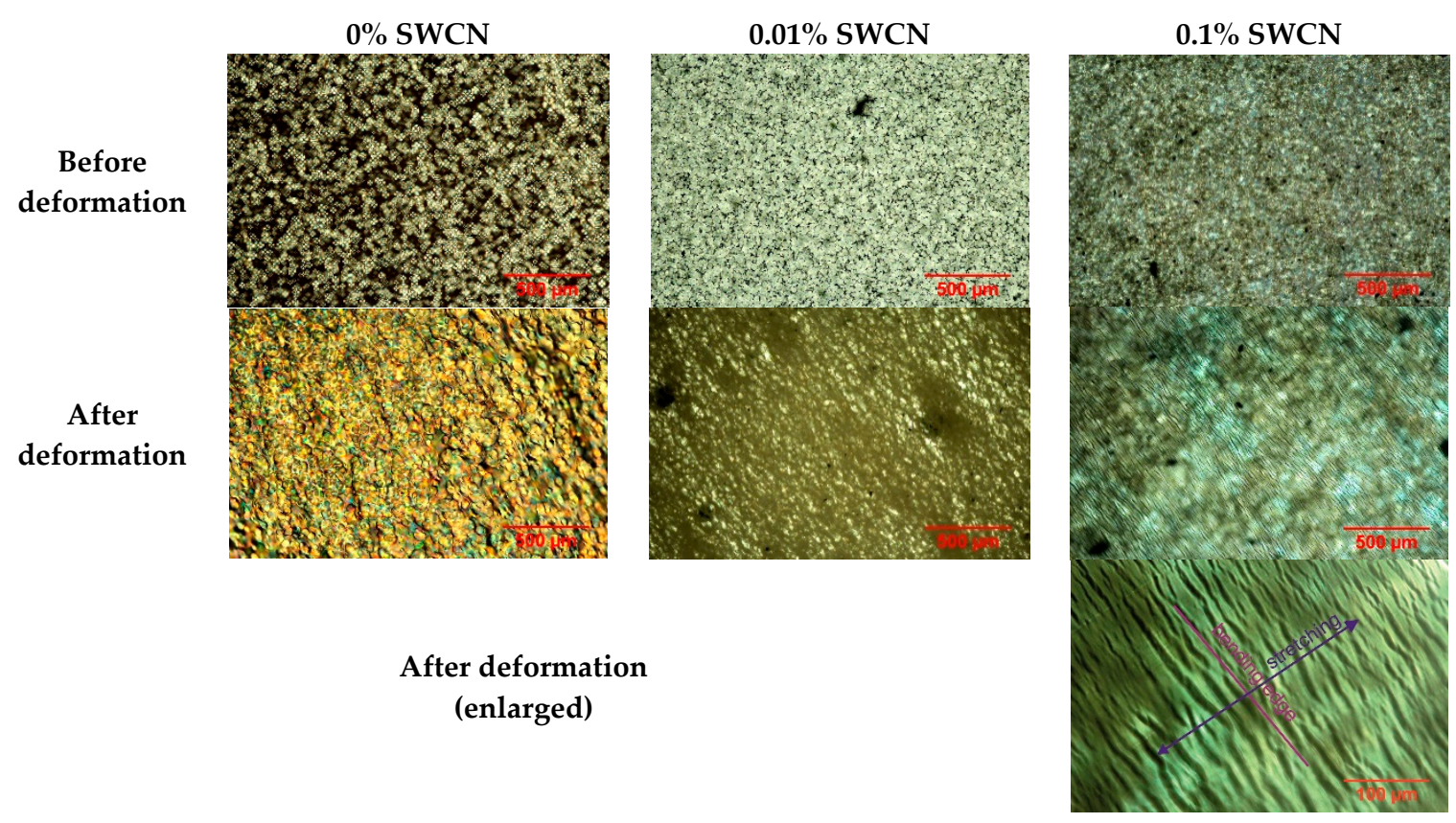

Figure 6. Optical texture for L,D-PLA and its mixtures with SWCN before and after mechanical deformations; room temperature, crossed polarizers $\left(90^{\circ}\right)$.

\subsection{Conductivity of Hybrid Films}

Based on the measured resistivity $(R)$ and thickness $(d)$ of the samples, the conductivity $(\sigma)$ was calculated before and after deformation of the samples [52]:

$$
\sigma==\frac{1}{R} \frac{\ln 2}{\pi d}
$$

All measured and calculated results are gathered in Table 1. Mixtures with concentrations of SWCN lower than $0.1 \%$ are dielectrics (as shown below), and they are omitted from Table 1 . It is seen that the conductivity is the lowest for the composite with a SWCN concentration of $0.1 \%$, and increases when increasing the SWCN concentration. Moreover, the influence of deformation on conductivity is that conductivity value is lowered after deformation.

Measurements of dielectric permittivity were done for three samples: pure L,D-PLA and L,D-PLA with SWCN concentrations equal to $0.01 \%$ and $0.1 \%$, because mixtures with higher concentrations are good conductors (see Table 1). The dielectric spectra registered at room temperature for these three thin films are presented in Figure 7. As can be seen, the amount of SWCN has an influence on the dielectric spectra. While layers prepared with L,D-PLA without SWCN are dielectric with a very clearly visible relaxation at $100 \mathrm{~Hz}$, the layer with $0.1 \%$ SWCN is conductive, and relaxation is not visible. In turn, for the layer with a SWCN concentration of $0.01 \%$, a weak relaxation is still visible. Moreover, 
dielectric dispersion $\varepsilon^{\prime}$ at the low-frequency limit for the composite with a SWCN concentration of $0.01 \%$ (Figure $7 \mathrm{c}$ ) is noticeably higher than for the pure L,D-PLA sample (Figure 7a). On the other hand, for the mixture with a SWCN concentration of $0.1 \%$, the dielectric dispersion is characteristic of conductive materials (Figure 7e).
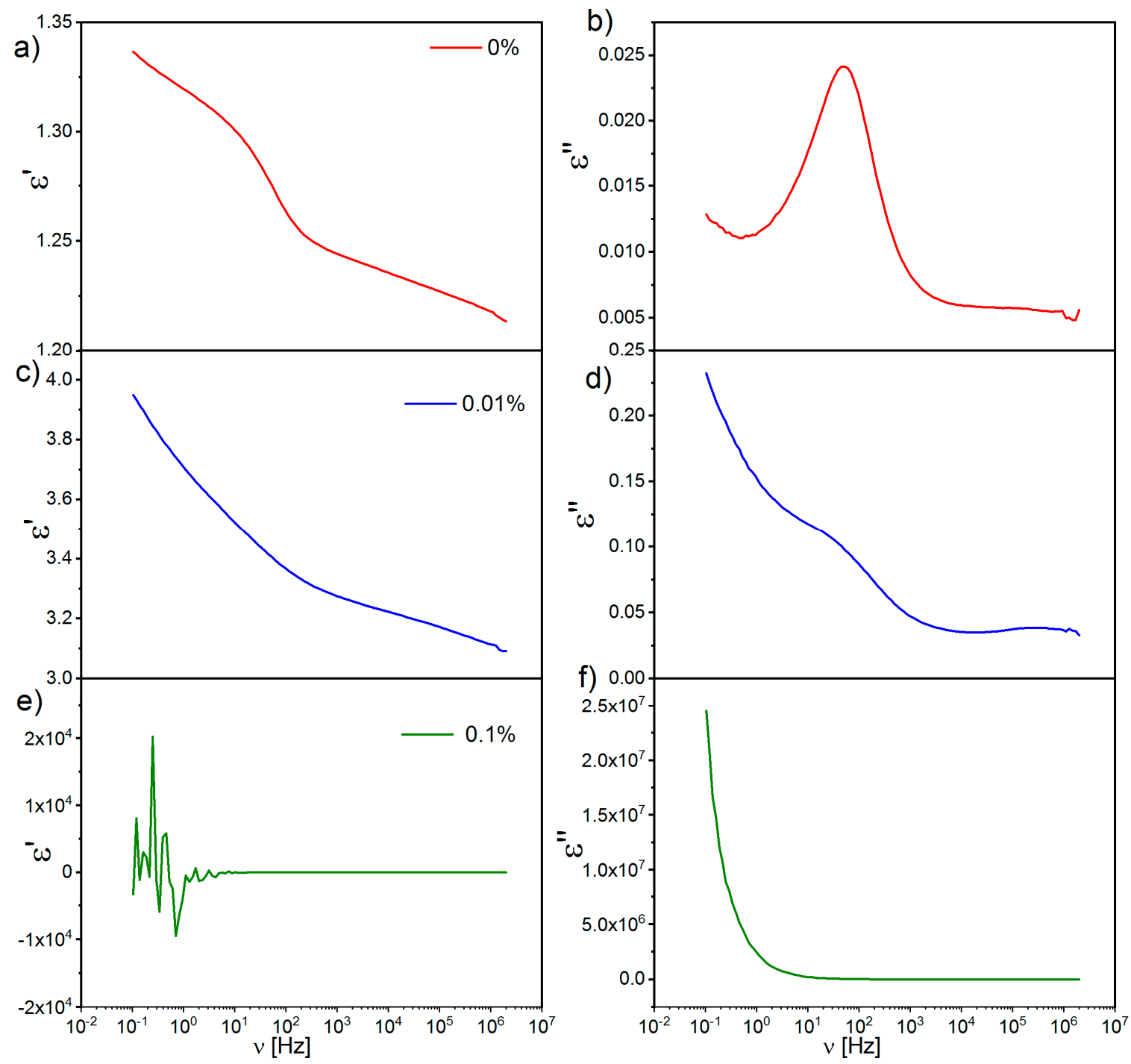

Figure 7. Dielectric dispersion (a) and absorption (b) registered for pure L,D-PLA, dielectric dispersion (c) and absorption (d) registered for mixture with SWCN content of $0.01 \%$, dielectric dispersion (e) and absorption (f) registered for mixture with SWCN content of $0.1 \%$; room temperature.

\subsection{Thermal Images of L,D-PLA with SWCN before and after Bending}

Thermal images of the L,D-PLA self-supported thin films containing different amounts of SWCN were acquired with a thermographic camera at different bias potentials, to observe IR emission due to current flux (i.e., Joule heating) and to detect possible current shunts. Figure 8 presents the correlation of temperature and current at different applied potentials for films based on pure and hybrid L,D-PLA. The samples of L,D-PLA with $0.01 \%, 0.1 \%$ and $1 \%$ SWCN did not reveal any temperature change with applied potential in the range from 0 to $32 \mathrm{~V}$, and no current was observe above $0.01 \mathrm{~A}$. These findings are in good accordance with electrical experiments; the samples with lower SWCN content showed higher values of ohmic resistance among all the tested materials. 

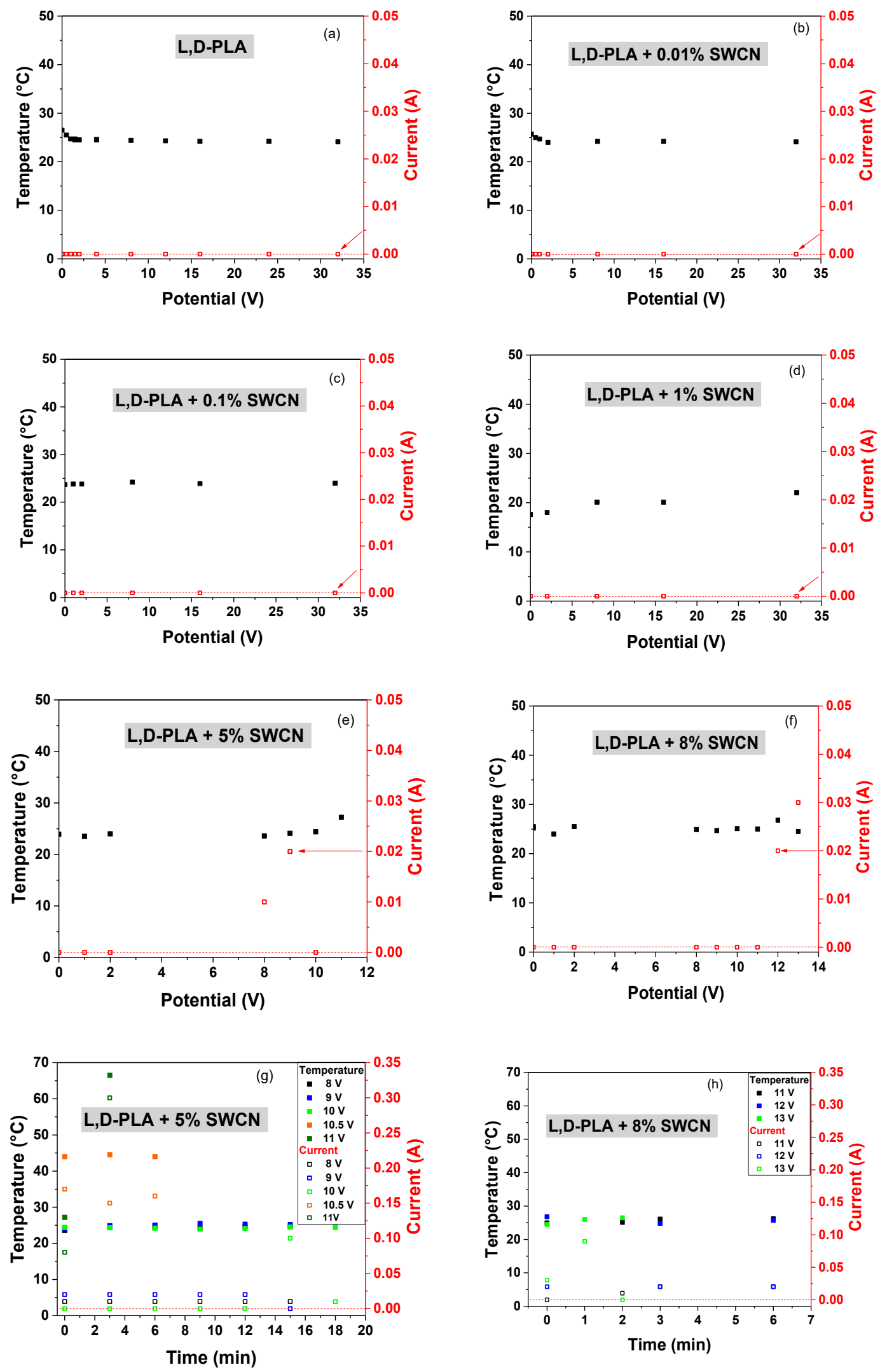

Figure 8. The correlation of temperature and current at different applied potentials for the film L,D-PLA (a) and films based on L,D-PLA containing $0.01 \%(\mathbf{b}), 0.1 \%(\mathbf{c}), 1 \%(\mathbf{d}), 5 \%(\mathbf{e})$ and $8 \%(\mathbf{f})$ SWCN, together with the correlation of temperature and current over time for films based on L,D-PLA containing $5 \%$ (g) and 8\% (h) SWCN; before mechanical deformation. 
On the other hand, samples containing $5 \%$ and $8 \%$ of SWCN (see Figure $8 \mathrm{e}, \mathrm{f}$ ) are much better conducting materials due to higher content of carbon additives and demonstrated an increase of temperature when applying different bias potentials. The analyses of the IR images, represented as temperature and current correlation vs. applied potential, are presented in Figure 8. An increase in the temperature was observed at 9 and $12 \mathrm{~V}$ for contents of $5 \%$ SWCN and $8 \%$ SWCN, respectively. Only one peculiar behavior was observed for films with 5\% SWCN: when increasing the potential from 9 to $10 \mathrm{~V}$, the current suddenly drops below the level of $0.01 \mathrm{~A}$, which might suggest a local polarization and local charge accumulation on the surface of the insulator domains [53], which in this case would be related to the presence of L,D-PLA.

Regarding the time-dependent measurements at fixed values of applied potentials, the following tendency was observed: for currents at level of $0.01 \mathrm{~A}$, no increase of temperature was observed; whereas for currents above $0.1 \mathrm{~A}$, there was an increase in the temperature of the sample, as can be seen in Figure 8g,h.

Analyzing the images with regard to the temperature distribution on the example of L,D-PLA with $5 \%$ SWCN (Figure 9), it can be observed that the zone of increased temperature appeared at the side of the alumina contactors, at the interface between the electric contactors and the tested film (Figure 9b); when the current was equal to $0.08 \mathrm{~A}$, the temperature increased from 24 to $27.2^{\circ} \mathrm{C}$. When the current reached a value of $0.3 \mathrm{~A}$, the sample temperature also increased to $66.5^{\circ} \mathrm{C}$ (Figure 9c).

In the following step, analysis of the film after mechanical deformation was performed. The results, showing the correlation of the temperature and current with applied potential for pure L,D-PLA in the samples containing $0.01 \%, 0.1 \%$ and $1 \%$ SWCN in the polymeric matrix are shown in Figure 10 . These samples did not reveal any temperature change in the range of applied potential from 0 to $32 \mathrm{~V}$, and no current flow was observed above $0.01 \mathrm{~A}$. Therefore, materials before and after mechanical deformation present similar properties.

Similar to previous findings, only samples containing 5\% and $8 \%$ SWCN did not lose their conducting properties after mechanical deformation; however, some deterioration in the performance was noticed (Figure 11a). Increasing the potential to $14 \mathrm{~V}$, the maximum observed currents were on levels up to 0.05 and $0.01 \mathrm{~A}$ for $5 \%$ and $8 \%$, respectively, which were similar to the results before deformation. Moreover, no temperature change of the sample was observed for $8 \%$ SWCN content.

Considering the application of constant potential over time, only in the case of $5 \%$ addition of SWCN was an increase in the temperature observed, along with an increase in current flux, as can be seen in Figure 11b. 

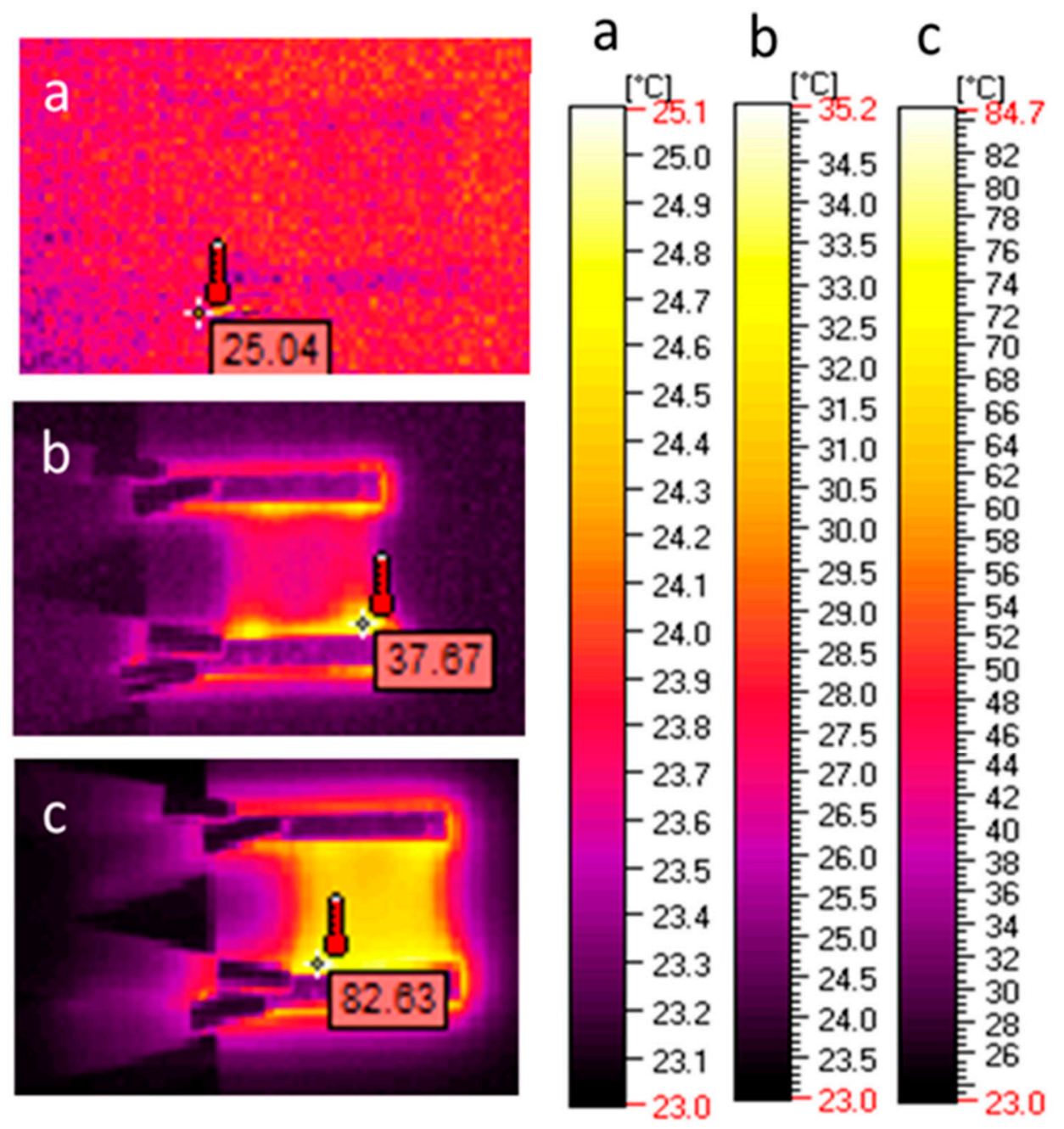

Figure 9. IR mages obtained for L,D-PLA with $5 \%$ SWCN under different potential value: 2 V, 0 A (a); $11 \mathrm{~V}, 0.08 \mathrm{~A}(\mathbf{b})$; and $11 \mathrm{~V}, 0.3 \mathrm{~A}(\mathbf{c})$.
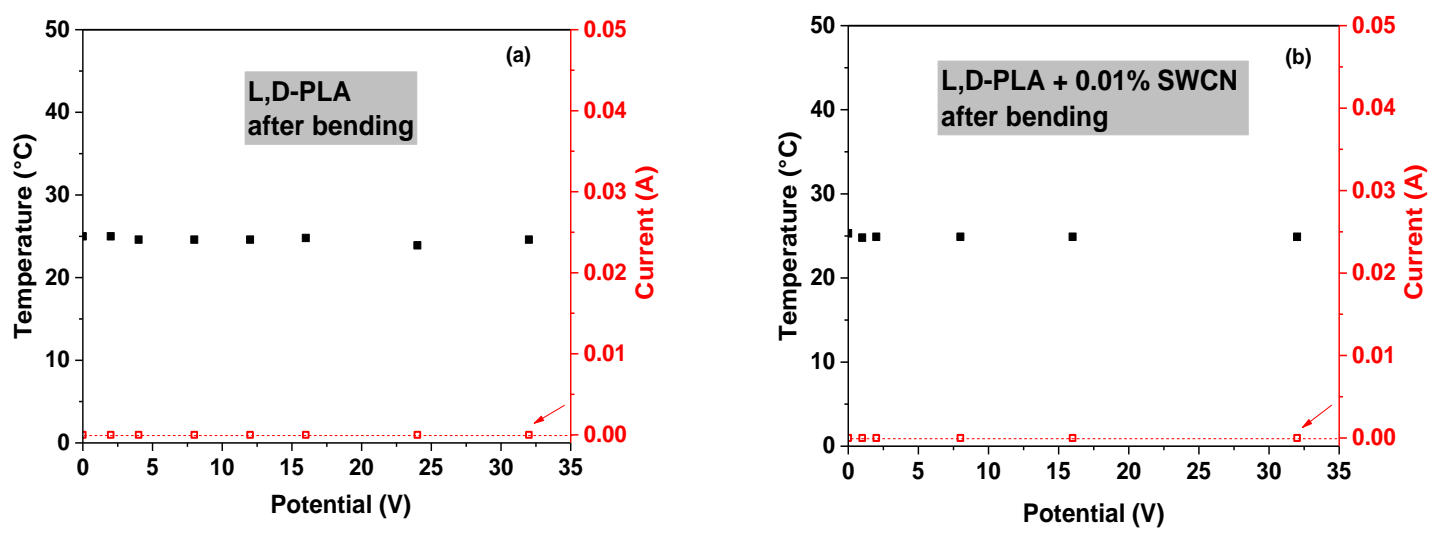

Figure 10. Cont. 

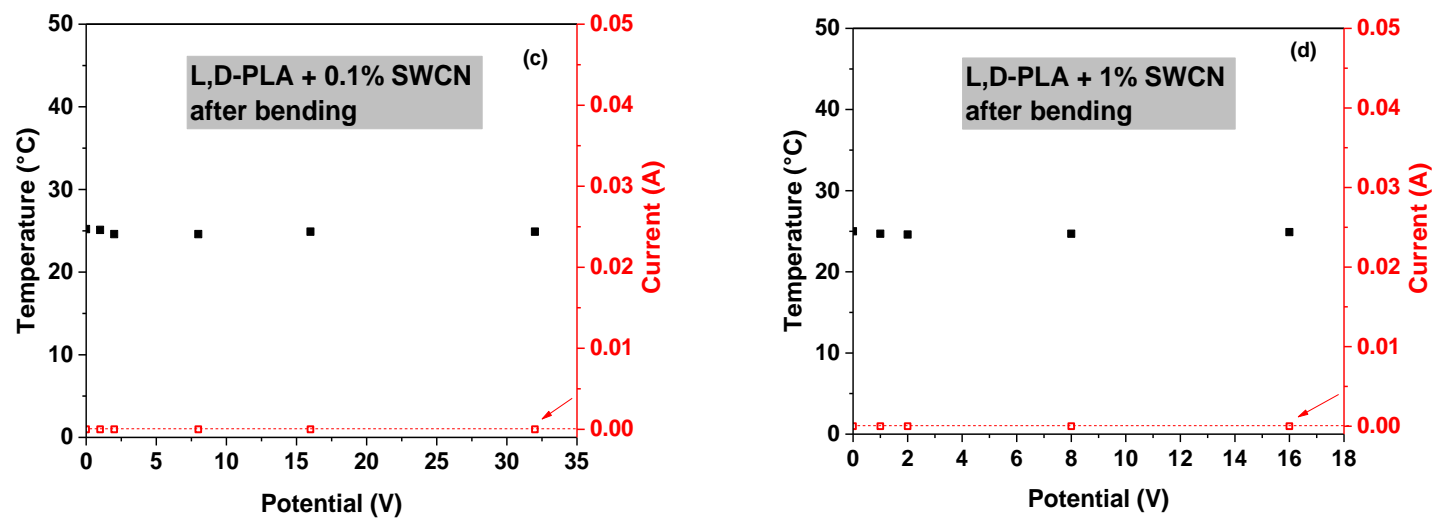

Figure 10. The correlation of temperature and current at different applied potentials for L,D-PLA film (a), and films based on L,D-PLA containing $0.01 \%$ (b), $0.1 \%$ (c) and $1 \%$ (d) SWCN; after mechanical deformation.
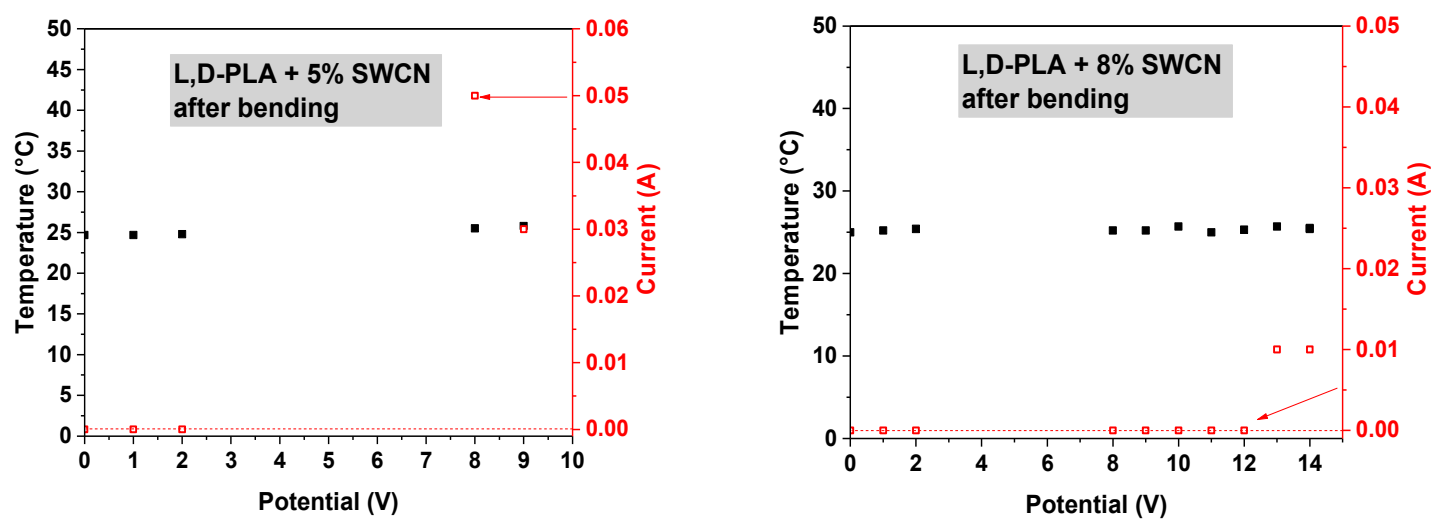

(a)
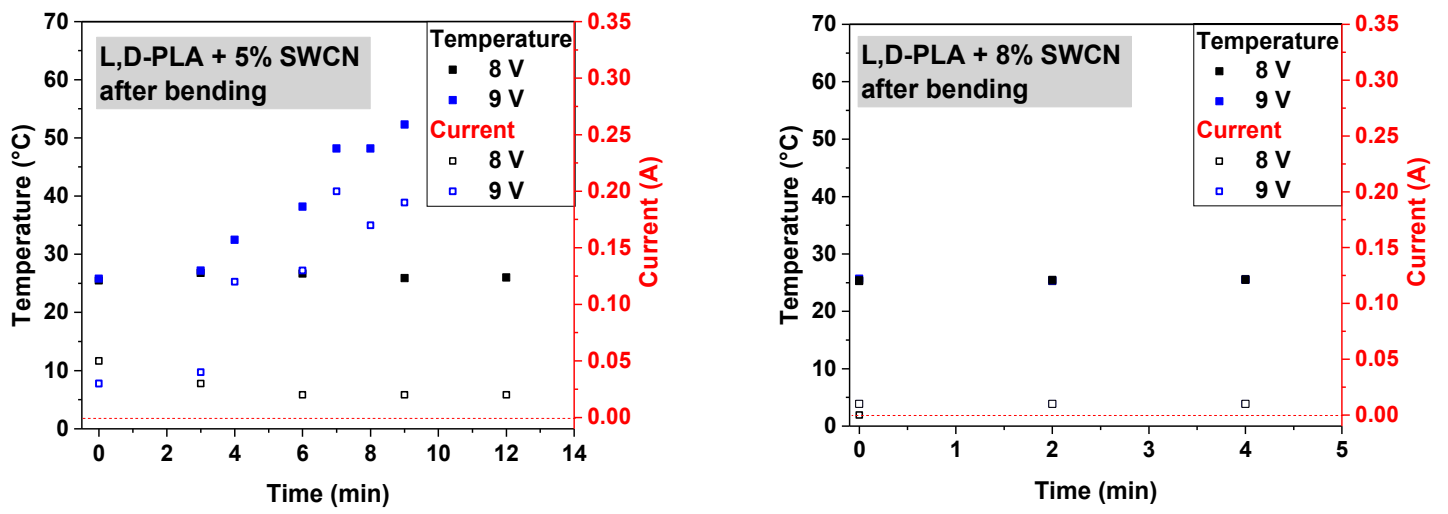

(b)

Figure 11. The correlation of temperature and current at different applied potentials (a) and the correlation of temperature and current over time (b) for films based on L,D-PLA containing $5 \%$ and $8 \%$ SWCN; after mechanical deformation.

The analysis of the homogeneity of the temperature distribution on the example of L,D-PLA with $5 \%$ SWCN after deformation (Figure 12), showed the differentiation of the heating zone. The line of the bending was located in the middle of the sample, perpendicular to the aluminum contactors. As previously mentioned, heating starts from the interface between the $\mathrm{Al}$ contactors and the sample (Figure 12a), and expands only on the top side of sample, where the electric circuit is the shortest, 
marking the bending line (Figure 12b). However over time, the temperature increases and expands over the whole sample (Figure 12c,d).
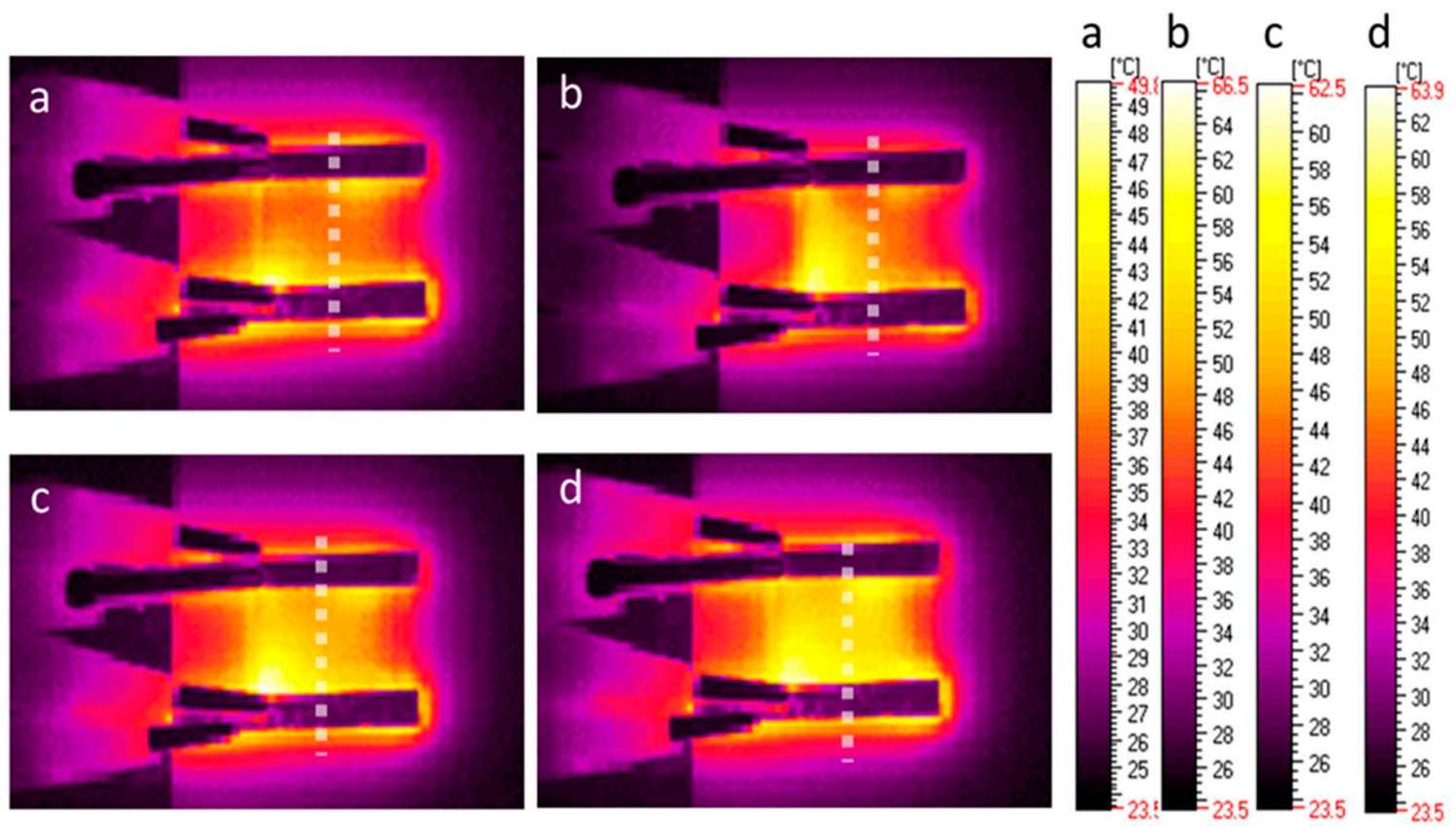

Figure 12. IR images obtained for L,D-PLA with $5 \%$ SWCN under different potential values: $9 \mathrm{~V}$, $0.13 \mathrm{~A}, 6 \mathrm{~min}(\mathbf{a}) ; 9 \mathrm{~V}, 0.2 \mathrm{~A}, 7 \mathrm{~min}(\mathbf{b}) ; 9 \mathrm{~V}, 0.17 \mathrm{~A}, 8 \mathrm{~min}(\mathbf{c})$; and 9 V, $0.02 \mathrm{~A}, 9 \mathrm{~min}(\mathbf{d})$; after mechanical deformation.

\subsection{Mechanical Properties of L,D-PLA with SWCN}

Mechanical properties were studied on prepared thin films to elucidate the influence of carbon nanotubes on mechanical resistance. All results are listed in Table 2. As can be seen from the relation of stress at break for different samples (Figure 13a), a small amount of SWCN such as $0.01 \%$ has a significant impact on material properties, resulting in an almost 3-fold decrease in stress resistance during elongation compared to pure L,D-PLA. For other SWCN concentrations, the stress values are lower than for pure polymers but do not surpass the value for L,D-PLA with $0.01 \%$ SWCN. This finding could be related to the formation of microdomains; hence, the interaction with the matrix is limited due to the possibility of weakening the structure [54].

Table 2. Tensile test performance on L,D-PLA with different contents of SWCN.

\begin{tabular}{cccccc}
\hline Composition & $\begin{array}{c}\text { Thickness } \\
(\mathbf{m m})\end{array}$ & $\begin{array}{c}\text { Cross-Section } \\
\text { Area }\left(\mathbf{m m}^{\mathbf{2}}\right)\end{array}$ & Length $(\mathbf{m m})$ & $\begin{array}{c}\text { Stress at Break } \\
\mathbf{( M P a})\end{array}$ & $\begin{array}{c}\text { Elongation at } \\
\text { Break } \mathbf{( \% )}\end{array}$ \\
\hline L,D-PLA & 0.038 & 0.38 & 18.22 & $71.0 \pm 8.9$ & $112.7 \pm 25.4$ \\
L,D-PLA + 0.01\% SWCN & 0.145 & 1.45 & 19.82 & $21.8 \pm 3.8$ & $104.2 \pm 14.0$ \\
L,D-PLA + 0.1\% SWCN & 0.047 & 0.47 & 17.86 & $57.8 \pm 5.6$ & $104.4 \pm 28.2$ \\
L,D-PLA + 1\% SWCN & 0.054 & 0.54 & 17.66 & $39.4 \pm 5.8$ & $103.4 \pm 17.4$ \\
L,D-PLA + 5\% SWCN & 0.034 & 0.34 & 19.9 & $45.6 \pm 1.5$ & $103.5 \pm 7.8$ \\
L,D-PLA + 8\% SWCN & 0.044 & 0.44 & 19.08 & $31.1 \pm 8.7$ & $103.4 \pm 9.9$ \\
\hline
\end{tabular}

Also, a tendency can be observed for other samples: with SWCN content starting from $0.1 \%$ and increasing to $8 \%$, the stress values declined gradually from approximately 60 to $31 \mathrm{MPa}$, taking into account the experimental error. This can be explained by the loss of plasticity with increased content of SWCN.

Taking into account elongation at break (Figure 13b), the materials showed similar results, regardless of the specific content of SWCN in the L,D,-PLA matrix, giving an increase of only up to $4 \%$ of the original length. 

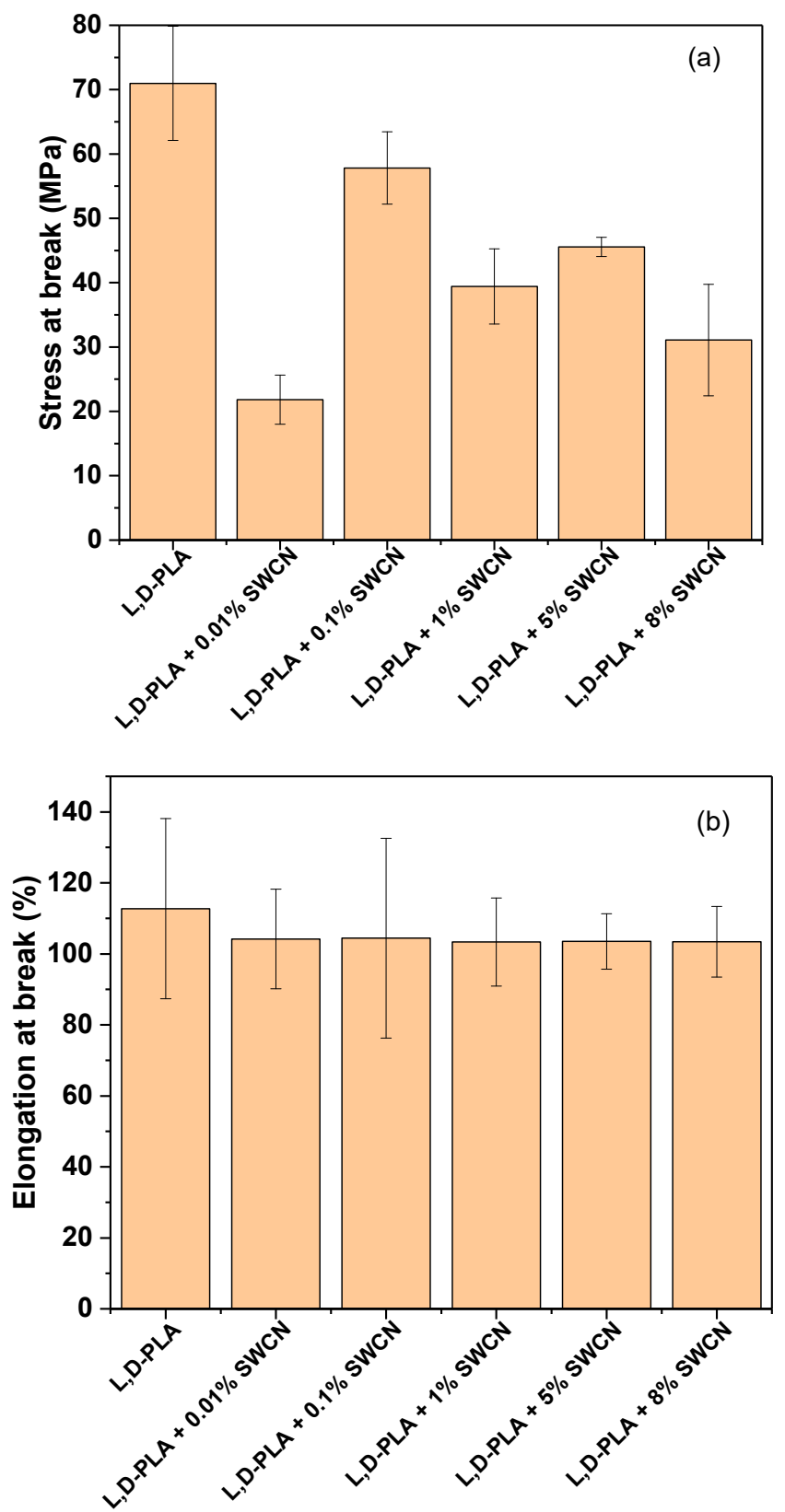

Figure 13. Stress at break (a) and elongation at break (b) of L,D-PLA with SWCN.

\subsection{Changes in the Chemical Structures of L,D-PLA by SWCN Studied by FT-IR}

FT-IR spectra were obtained in order to investigate whether changes in the chemical bonds, after embedding carbon nanotubes (SWCN) in a L,D-PLA matrix, occur. Figure 14 presents the spectra in the whole spectral range between 3100 and $500 \mathrm{~cm}^{-1}$.

In the spectrum of pure L,D-PLA, the most prominent bands are connected to $v(C-O)$ and $v(C=O)$ stretching modes. The first occur in the spectral range of $1300-1000 \mathrm{~cm}^{-1}$ and the second one is placed at $1748 \mathrm{~cm}^{-1}$. The spectrum also contains stretching and bending vibrations of $\mathrm{CH}_{3}$ methyl groups, which occur in the spectral ranges of $3100-2800$ and $1480-1300 \mathrm{~cm}^{-1}$, respectively. In the low wavenumber range (below $1000 \mathrm{~cm}^{-1}$ ), the $v(C-C)$ modes are present at 869 and $754 \mathrm{~cm}^{-1}$ [55]. The IR spectrum of L,D-PLA fully confirms its proper composition-all the expected essential bands are present in the spectrum. Comparing the results in Figure 14, it can be seen that the spectrum of pure L,D-PLA and the spectra of L,D-PLA/SWCN composites with different SWCN compositions (from 0.01 to $8 \%$ ) are similar, but some differences are also clearly visible. This means that SWCN moderate 
L,D-PLA, but do not change the molecular structure of the polymer. The most prominent changes in these spectra can be observed in four spectral ranges (Figure 15), especially for the compositions with $5 \%$ and $8 \%$ SWCN.

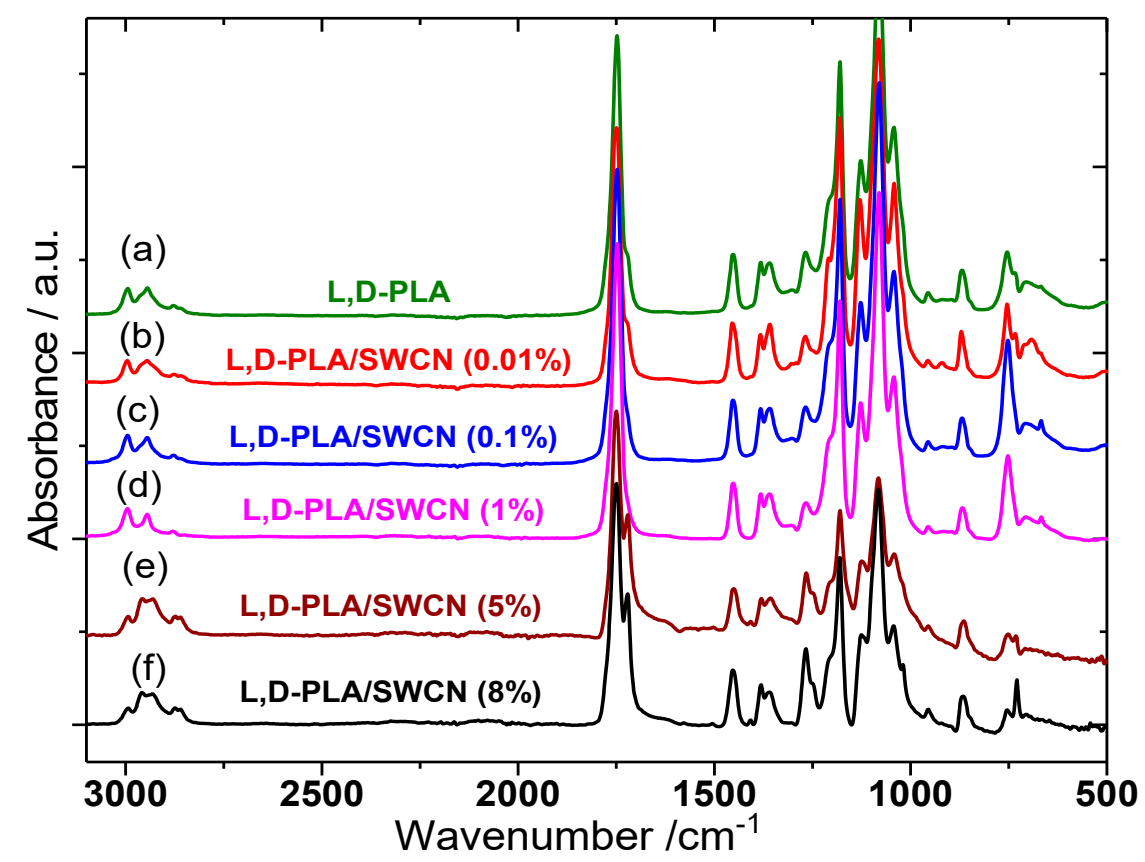

Figure 14. FT-IR spectra of L,D-PLA and L,D-PLA/SWCN composites (a-f) obtained at $293 \mathrm{~K}$.
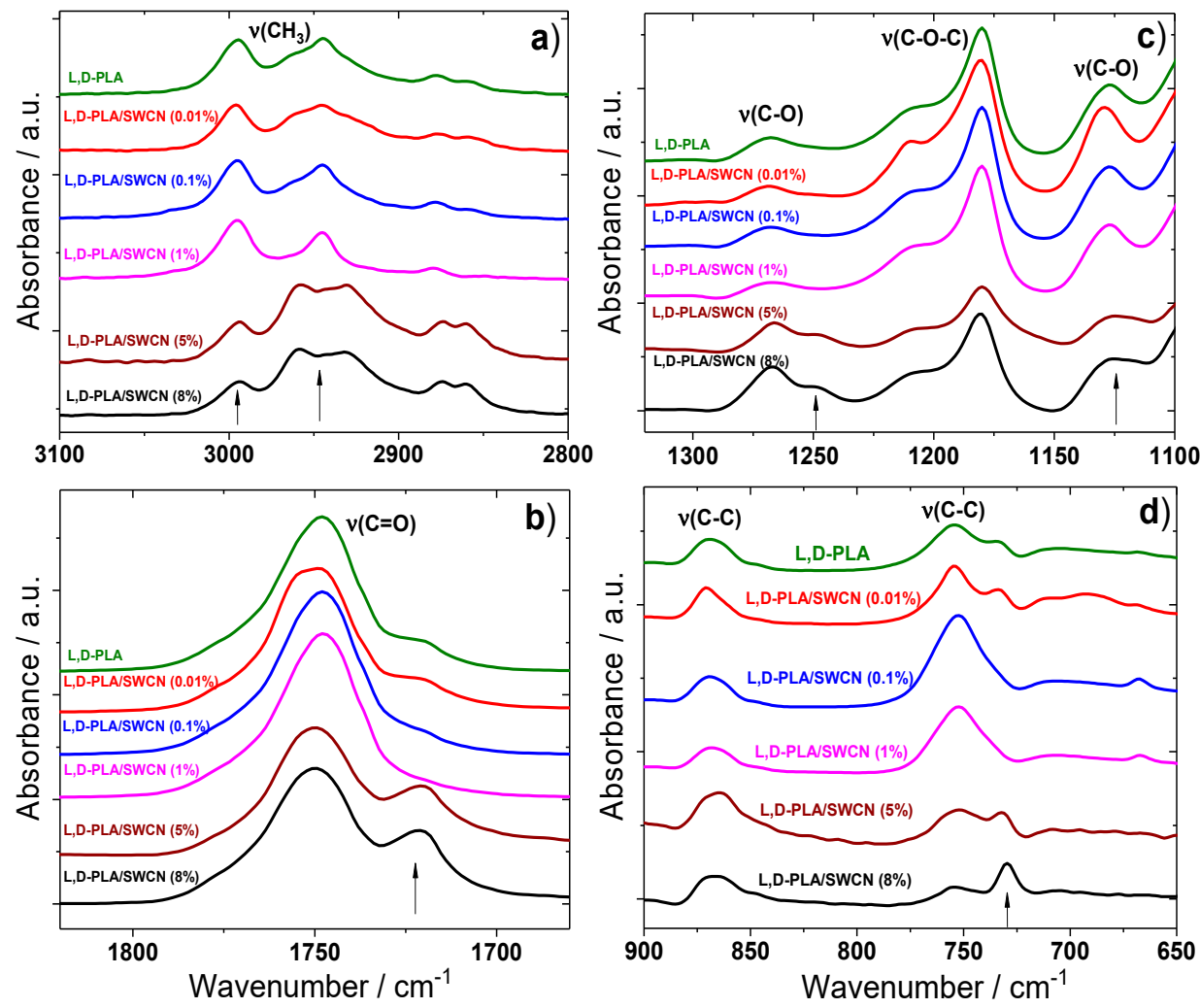

Figure 15. FT-IR spectra of L,D-PLA and L,D-PLA/SWCN composites with different compositions in four different spectra ranges: (a) 3100-2800, (b) 1820-1680, (c) 1320-1100 and (d) 900-650 cm-1. The bands which change significantly are marked with arrows. 
First, in the high-wavenumber range, changes in the bands connected to $v\left(\mathrm{CH}_{3}\right)$ stretching modes are observed (Figure 15a). The band at $2995 \mathrm{~cm}^{-1}$ significantly decreases its intensity in the case of L,D-PLA with $5 \%$ and $8 \%$ SWCN. The shape of the band with a maximum at $2944 \mathrm{~cm}^{-1}$ also changes. It contains three components in pure L,D-PLA: the main one at $2944 \mathrm{~cm}^{-1}$ and two shoulders on the sides at 2964 and $2929 \mathrm{~cm}^{-1}$. A small amount of SWCN $(0.1 \%)$ causes the band to become single, but increasing the amount of SWCN to $5 \%$ and $8 \%$ causes a large increase in the intensities of the two shoulders. Also, the bands at 1748 and $1266 \mathrm{~cm}^{-1}(v(\mathrm{C}=\mathrm{O})$ and $v(\mathrm{C}-\mathrm{O})$ modes, respectively) split into two components, and the band at $1127 \mathrm{~cm}^{-1}(v(\mathrm{C}-\mathrm{O})$ mode) becomes much broader in the case of the L,D-PLA/SWCN composites with the two highest amounts of SWCN used (Figure 15b,c). Some additional changes can be observed in the low-wavenumber range, where the bands at 754 and $733 \mathrm{~cm}^{-1}$ connected with $v(\mathrm{C}-\mathrm{C})$ modes are located (Figure 15d). The band at $733 \mathrm{~cm}^{-1}$ decreases in intensity with an increase in the amount of SWCN to $1 \%$. With further increase in the SWCN content, the intensity of this band suddenly increases-for the L,D-PLA/SWCN at $8 \%$, this band becomes more intense than the one at $754 \mathrm{~cm}^{-1}$.

In the case of the band at $754 \mathrm{~cm}^{-1}$, related to the crystalline region, the opposite situation occurs. Namely, a small amount of SWCN $(0.01 \%)$ does not significantly change this band compared to pure L,D-PLA. In turn, addition of $0.1 \%$ or $1 \%$ of SWCN causes a large increase in the intensity of this band. With a further increase in the amount of SWCN ( $5 \%$ and $8 \%$ ), a sudden drop in intensity is observed. The spectroscopic results indicate that in the case of L,D-PLA/SWCN composites, bonding interactions between the polymer molecules and SWCN occur, and all parts of the polymer are involved. Moreover, from the point of view of the FT-IR method, small amounts of SWCN (up to 1\%) moderate L,D-PLA in different ways from larger amounts of SWCN ( $5 \%$ or $8 \%$ ). The crystallinity of L,D-PLA increases with the addition of SWCN up to $1 \%$, whereas a larger amount of SWCN $(5 \%$ and $8 \%)$ causes its decrease.

\subsection{Changes in the Chemical Structures of L,D-PLA by SWCN Studied by ${ }^{1} H$ NMR}

${ }^{1} \mathrm{H}$ NMR study was performed on samples containing different amounts of SWCN, in order to detect possible interactions with polymeric matrix. Since the sample are a physical mixture of L,D-PLA and SWCN, no additional signals appeared in the spectra compared to the reference pure L,D-PLA spectrum, as expected. However, the addition of nanomaterials cause broadening of all signals. It was found that the greater the amount of SWCN in sample, the broader the signals (see Figure 16). It seems that carbon nanotubes have an influence on the integrity of the film, and the dissolution process occurs via a swelling due to the possible stabilization of the polymeric matrix with weak interactions.

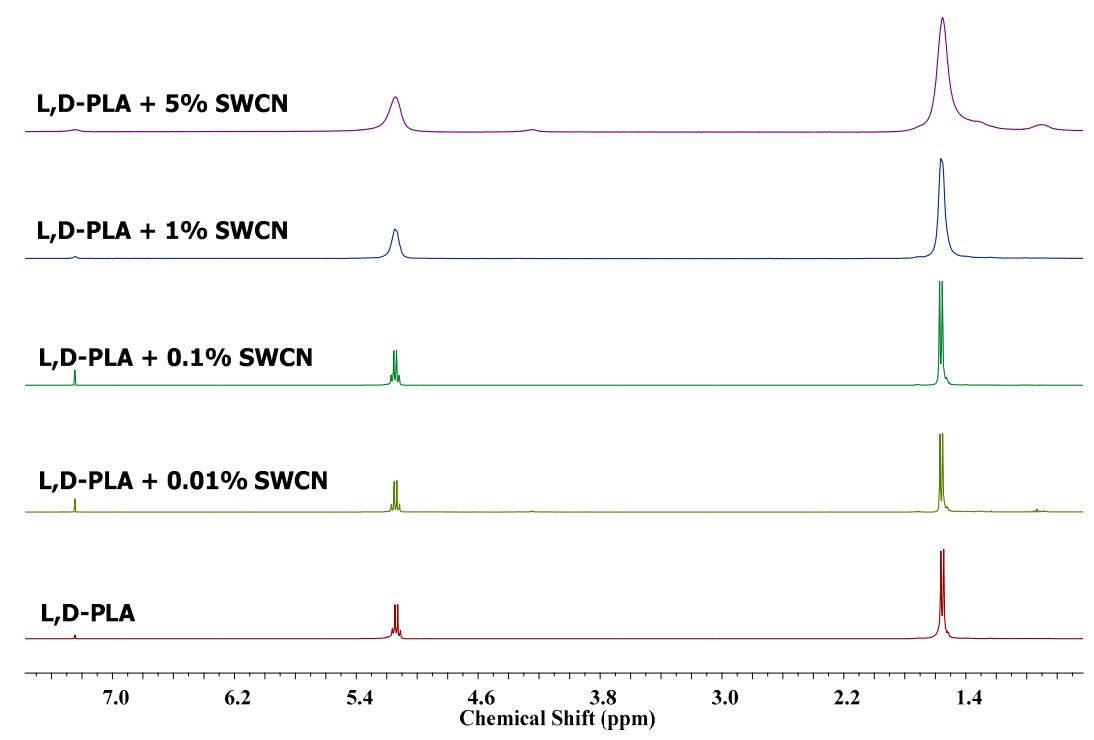

Figure 16. ${ }^{1} \mathrm{H}$ NMR spectra of pure L,D-PLA and its mixtures with SWCN. 


\section{Conclusions}

As presented in our work, L,D-poly(lactic acid), a known biodegradable polymer, can be used as a flexible and translucent substrate for organic devices, replacing other flexible materials such as PET. Our study showed that a $0.01 \%$ SWCN concentration gave translucent supports; however, it did not exhibit sufficient conductivity, which is required for good electric conductors. An increase in the amount of SWCN to $0.1 \%$ was accompanied by an increase in conductivity to about $1.01 \times \cdot 10^{3} \mathrm{~S} / \mathrm{m}$; however, the films were not fully translucent. Bending of this sample decreased conductivity to $8.51 \times \cdot 10^{2} \mathrm{~S} / \mathrm{m}$. The spectroscopic results indicated that in the case of L,D-PLA/SWCN composites at $5 \%$ and $8 \%$, bonding interactions between the polymer molecules and SWCN occur, and that all parts of the polymer are involved. It was found that the smallest amount of SWCN, $0.01 \%$, drastically decreases the mechanical properties of thin films, probably due to poor interaction with the polymeric matrix. Meanwhile, the addition of nanotubes from $0.1 \%$ to $8 \%$ has a smaller impact, and interacts better with the polymer structure. Based on our present results, as well as the discussed literature, the following future goals are proposed:

$\checkmark \quad$ Optimize technique used for creating hybrid films based on L,D-PLA/SWCN.

$\checkmark \quad$ Construct organic solar cells using our best L,D-PLA/SWCN films as translucent electrodes.

$\checkmark$ Introduce L,D-PLA as a flexible, green substrate to build organic solar cells with biodegradable properties.

Author Contributions: P.F. prepared the thin films, performed and analysed the resistivity, optical, calorimetric and dielectric studies. J.R. performed and analysed the optical studies. K.A.B. performed the thermal imaging experiments and analysed the data. P.K. and K.A.B. performed and analysed the mechanical study. N.G. performed and analysed FTIR study. M.M. (Mateusz Marzec) performed and analysed the topography studies. A.I. and M.M. (Monika Marzec) wrote the paper. A.I., M.M. (Monika Marzec) and A.J. contributed to the analysis and discussion.

Funding: Financial support from the Ministry of National Defense Republic of Poland (GB/2/2018/206/2018/DA) is gratefully acknowledged.

Acknowledgments: The authors express gratitude to the Ministry of National Defense Republic of Poland for financial support for General Tadeusz Kosciuszko Military University of Land Forces, Wroclaw under the 2018-2022 project entitled "New organic materials and hybrid compositions for optoelectronic devices" (No. GB/2/2018/206/2018/DA). The research (FT-IR, DSC, Dielectric spectroscopy) was carried out with the equipment purchased thanks to the financial support of the European Regional Development Fund in the framework of the Polish Innovation Economy Operational Program (contract no. POIG.02.01.00-12-023/08). The research (DektakXT (Bruker Co., Billerica, MA, USA) Stylus profilometer) was partially performed using equipment purchased with the financial support of National Science Centre, project agreement number UMO-2017/25/B/ST5/00575.

Conflicts of Interest: The authors declare no conflict of interest.

\section{References}

1. Bundgaard, E.; Krebs, F.C. Low band gap polymers for organic photovoltaics. Sol. Energy Mater. Sol. Cells 2007, 91, 954-985. [CrossRef]

2. Günes, S.; Neugebauer, H.; Sariciftci, N.S. Conjugated polymer-based organic solar cells. Chem. Rev. 2007, 107, 1324-1338. [CrossRef] [PubMed]

3. Zhan, X.; Zhu, D. Conjugated polymers for high-efficiency organic photovoltaics. Polym. Chem. 2010, 1, 409-419. [CrossRef]

4. Jayawardena, K.D.G.I.; Rozanski, L.J.; Mills, C.A.; Beliatis, M.J.; Nismy, N.A.; Silva, S.R.P. Inorganics-in-organics: Recent developments and outlook for $4 \mathrm{G}$ polymer solar cells. Nanoscale 2013, 5, 8411-8427. [CrossRef] [PubMed]

5. Cai, W.; Gong, X.; Cao, Y. Polymer solar cells: Recent development and possible routes for improvement in the performance. Sol. Energy Mater. Sol. Cells 2010, 94, 114-127. [CrossRef]

6. Li, Y. Molecular design of photovoltaic materials for polymer solar cells: Towards suitable electronic energy levels and broad absorption. Acc. Chem. Res. 2012, 45, 723-733. [CrossRef] [PubMed] 
7. Kesters, J.; Kudret, S.; Bertho, S.; van den Brande, N.; Defour, M.; van Mele, B.; Penxten, H.; Lutsen, L.; Manca, J.; Vanderzande, D.; et al. Enhanced intrinsic stability of the bulk heterojunction active layer blend of polymer solar cells by varying the polymer side chain pattern. Org. Electr. 2014, 15, 549-562. [CrossRef]

8. Chen, L.M.; Hong, Z.; Li, G.; Yang, Y. Recent progress in polymer solar cells: Manipulation of polymer:fullerene morphology and the formation of efficient inverted polymer solar cells. Adv. Mater. 2009, 21, 1434-1449. [CrossRef]

9. Venkataraman, D.; Yurt, S.; Venkatraman, B.H.; Gavvalapalli, N. Role of molecular architecture in organic photovoltaic cells. J. Phys. Chem. Lett. 2010, 1, 947-958. [CrossRef]

10. Chen, J.T.; Hsu, C.S. Conjugated polymer nanostructures for organic solar cell applications. Polym. Chem. 2011, 2, 2707-2722. [CrossRef]

11. Dennler, G.; Scharber, M.C.; Brabec, C.J. Polymer-fullerene bulk-heterojunction solar cells. Adv. Mater. 2009, 21, 1323-1338. [CrossRef]

12. Nunzi, J.M. Organic photovoltaic materials and devices. C. R. Phys. 2002, 3, 523-542. [CrossRef]

13. Scharber, M.C.; Sariciftci, N.S. Efficient of bulk-heterojunction organic solar cells. Prog. Polym. Sci. 2013, 38, 1929-1940. [CrossRef] [PubMed]

14. Notarianni, M.; Vernon, K.; Chou, A.; Aljada, M.; Liu, J.; Motta, N. Plasmonic effect of gold nanoparticles in organic solar cells. Sol. Energy 2014, 106, 23-37. [CrossRef]

15. Zhou, H.; Yang, L.; You, W. Rational design of high performance conjugated polymers for organic solar cells. Macromolecules 2012, 45, 607-632. [CrossRef]

16. Iwan, A.; Chuchmała, A. Perspectives of Applied Graphene: Polymer Solar Cells. Prog. Polym. Sci. 2012, 37, 1805-1828. [CrossRef]

17. Krebs, F.C.; Jørgensen, M.; Norrman, K.; Hagemann, O.; Alstrup, J.; Nielsen, D.; Fyenbo, J.; Larsen, K.; Kristensen, J. A complete process for production of flexible large area polymer solar cells entirely using screen printing-First public demonstration. Sol. Energy Mater. Sol. Cells 2009, 93, 422-441. [CrossRef]

18. Krebs, F.C.; Gevorgyan, S.A.; Alstrup, J. A roll-to-roll process to flexible polymer solar cells: Model studies, manufacture and operational stability studies. J. Mater. Chem. 2009, 19, 5442-5451. [CrossRef]

19. Kaltenbrunner, M.; White, M.S.; Glowacki, E.D.; Sekitani, T.; Someya, T.; Sariciftci, N.S.; Bauer, S. Ultrathin and lightweight organic solar cells with high flexibility. Nat. Commun. 2012, 3, 770. [CrossRef] [PubMed]

20. Kopola, P.; Aernouts, T.; Sliz, R.; Guillerez, S.; Ylikunnari, M.; Cheyns, D.; Valimaki, M.; Tuomikoski, M.; Hast, J.; Jabbour, G.; et al. Gravure printed flexible organic photovoltaic modules. Sol. Energy Mater. Sol. Cells 2011, 95, 1344-1347. [CrossRef]

21. Kopola, P.; Zimmermann, B.; Filipovic, A.; Schleiermacher, H.; Greulich, J.; Rousu, S.; Hast, J.; Myllyla, R.; Wurfel, U. Aerosol jet printed grid for ITO-free inverted organic solar cells. Sol. Energy Mater. Sol. Cells 2012, 107, 252-258. [CrossRef]

22. Lim, J.-V.; Cho, D.-Y.; Kim, J.; Na, S.-I.; Kim, H.-K. Simple brush-painting of flexible and transparent Ag nanowire network electrodes as an alternative ITO anode for cost-efficient flexible organic solar cells. Sol. Energy Mater. Sol. Cells 2012, 107, 348-354. [CrossRef]

23. Gong, S.C.; Jang, S.K.; Ryu, S.O.; Jeon, H.; Park, H.-H.; Chang, H.J. Post annealing effect of flexible polymer solar cells to improve their electrical properties. Curr. Appl. Phys. 2010, 10, 192-196. [CrossRef]

24. Lee, B.J.; Kim, H.J.; Jeong, W.-I.; Kim, J.-J. A transparent conducting oxide as an efficient middle electrode for flexible organic tandem solar cells. Sol. Energy Mater. Sol. Cells 2010, 94, 542-546.

25. Galagan, Y.; Rubingh, J-.J.M.; Andriessen, R.; Fan, C.-C.; Blom, P.W.M.; Veenstra, S.C.; Kroon, J.M. ITO-free flexible organic solar cells with printed current collecting grids. Sol. Energy Mater. Sol. Cells 2011, 95, 1339-1343. [CrossRef]

26. Bedeloglu, A.; Demir, A.; Bozkurt, Y.; Sariciftci, N.S. A flexible textile structure based on polymeric photovoltaics using transparent cathode. Synth. Met. 2009, 159, 2043-2048. [CrossRef]

27. Angmo, D.; Krebs, F.C. Flexible ITO-free polymer solar cells. J. Appl. Polym. Sci. 2013, 129, 1-14. [CrossRef]

28. De Arco, L.G.; Zhang, Y.; Schlenker, C.W.; Ryu, K.; Thompson, M.E.; Zhou, C. Continuous, highly flexible, and transparent graphene films by chemical vapor deposition for organic photovoltaics. ACS Nano 2010, 4, 2865-2873. [CrossRef] [PubMed]

29. Lee, S.-K.; Rana, K.; Ahn, J.-H. Graphene films for flexible organic and energy storage devices. J. Phys. Chem. Lett. 2013, 4, 831-841. [CrossRef] [PubMed] 
30. Park, H.; Rowehl, J.A.; Kim, K.K.; Bulovic, V.; Kong, J. Doped graphene electrodes for organic solar cells. Nanotechnology 2010, 21, 505204. [CrossRef] [PubMed]

31. Yin, Z.; Sun, S.; Salim, T.; Wu, S.; Huang, X.; He, Q.; Lam, Y.M.; Zhang, H. Organic photovoltaic devices using highly flexible reduced graphene oxide films as transparent electrodes. ACS Nano 2010, 4, 5263-5268. [CrossRef] [PubMed]

32. Lee, S.; Yeo, J.-S.; Ji, Y.; Cho, C.; Kim, D.-Y.; Na, S.-I.; Lee, B.H.; Lee, T. Flexible organic solar cells composed of P3HT:PCBM using chemically doped graphene electrodes. Nanotechnology 2012, 23, 344013. [CrossRef] [PubMed]

33. Iwan, A.; Tazbir, I.; Sibiński, M.; Boharewicz, B.; Pasciak, G.; Schab-Balcerzak, E. Optical, electrical and mechanical properties of indium tin oxide on polyethylene terephthalate substrates: Application in bulk-heterojunction polymer solar cells. Mater. Sci. Semicond. Process. 2014, 24, 110-116. [CrossRef]

34. Chen, F.C.; Chien, S.C. Nanoscale functional interlayers formed through spontaneous vertical phase separation in polymer photovoltaic devices. J. Mater. Chem. 2009, 19, 6865-6869. [CrossRef]

35. Iwan, A.; Caballero-Briones, F.; Bogdanowicz, K.A.; Barceinas-Sánchez, J.D.O.; Przybyl, W.; Januszko, A.; Baron-Miranda, J.A.; Espinosa-Ramirez, A.P.; Guerrero-Contreras, J. Optical and electrical properties of graphene oxide and reduced graphene oxide films deposited onto glass and Ecoflex ${ }^{\circledR}$ substrates towards organic solar cells. Adv. Mater. Lett. 2018, 9, 58-65. [CrossRef]

36. Muller, J.; González-Martínez, C.; Chiralt, A. Combination of Poly(lactic) Acid and Starch for Biodegradable Food Packaging. Materials 2017, 10, 952. [CrossRef] [PubMed]

37. Gonçalves, C.; Gonçalves, I.C.; Magalhães, F.D.; Pinto, A.M. Poly(lactic acid) composites containing carbon-based nanomaterials: A review. Polymers 2017, 9, 269. [CrossRef]

38. Jamshidian, M.; Tehrany, E.A.; Imran, M.; Jacquot, M.; Desobry, S. Poly-lactic acid: Production, applications, nanocomposites, and release studies. Compr. Rev. Food Sci. Food Saf. 2010, 9, 552-571. [CrossRef]

39. Strange, M.; Plackett, D.; Kaasgaard, M.; Krebs, F.C. Biodegradable polymer solar cells. Sol. Energy Mater. Sol. Cells 2008, 92, 805-813. [CrossRef]

40. Singh, R.; Bhattacharya, B.; Rhee, H.-W.; Singh, P.K. New biodegradable polymer electrolyte for dye sensitized solar cell. Int. J. Electrochem. Sci. 2014, 9, 2620-2630.

41. Zhou, Y.; Fuentes-Hernandez, C.; Khan, T.M.; Liu, J.-C.; Hsu, J.; Shim, J.W.; Dindar, A.; Youngblood, J.P.; Moon, R.J.; Kippelen, B. Recyclable organic solar cells on cellulose nanocrystal substrates. Sci. Rep. 2013, 3, 1536. [CrossRef] [PubMed]

42. Lu, S.; Sun, Y.; Ren, K.; Liu, K.; Wang, Z.; Qu, S. Recent development in ITO-free flexible polymer solar cells. Polymers 2018, 10, 5. [CrossRef]

43. Du, J.; Pei, S.; Ma, L.; Cheng, H.M. 25th anniversary article: Carbon nanotube- and graphene-based transparent conductive films for optoelectronic devices. Adv. Mater. 2014, 26, 1958-1991. [CrossRef] [PubMed]

44. Calogero, G.; Bonaccorso, F.; Marago, O.M.; Gucciardi, P.G.; di Marco, G. Single wall carbon nanotubes deposited on stainless steel sheet substrates as novel counter electrodes for ruthenium polypyridine based dye sensitized solar cells. Dalton Trans. 2010, 39, 2903-2909. [CrossRef] [PubMed]

45. Husmann, S.; Zarbin, A.J.G. Multifunctional carbon nanotubes/ruthenium purple thin films: Preparation, characterization and study of application as sensors and electrochromic materials. Dalton Trans. 2015, 44, 5985-5995. [CrossRef] [PubMed]

46. Oka, S.; Ozawa, H.; Yoshikawa, K.; Ikeda, T.; Haga, M. Hydrogen-bonded metallo-supramolecular polymers based on ruthenium or iron complexes for the selective extraction of single-walled carbon nanotubes. Dalton Trans. 2018, 47, 14195-14203. [CrossRef] [PubMed]

47. Ma, P.; Lv, P.; Xu, P.; Du, M.; Zhu, H.; Dong, W.; Chen, M. Design of bio-based conductive and fast crystallizing nanocomposites with controllable distribution of multiwalled carbon nanotubes via interfacial stereocomplexation. Chem. Eng. J. 2018, 336, 223-232. [CrossRef]

48. Lei, L.; Qiu, J.; Sakai, E. Preparing conductive poly(lactic acid) (PLA) with poly(methyl methacrylate) (PMMA) functionalized graphene (PFG) by admicellar polymerization. Chem. Eng. J. 2012, 209, 20-27. [CrossRef]

49. Zhang, L.; Li, Y.; Wang, H.; Qiao, Y.; Chen, J.; Cao, S. Strong and ductile poly(lactic acid) nanocomposite films reinforced with alkylated graphene nanosheets. Chem. Eng. J. 2015, 264, 538-546. [CrossRef] 
50. Cui, C.-H.; Yan, D.-X.; Pang, H.; Jia, L.-C.; Xu, X.; Yang, S.; Xu, J.-Z.; Li, Z.-M. A high heat-resistance bioplastic foam with efficient electromagnetic interference shielding. Chem. Eng. J. 2017, 323, 29-36. [CrossRef]

51. Luckachan, G.E.; Pillai, C.K.S. Biodegradable polymers-A review on recent trends and emerging perspectives. J. Polym. Environ. 2011, 19, 637-676. [CrossRef]

52. Wieder, H. Laboratory Notes on Electrical and Galvanomagnetic Measurements (Materials Science); Elsevier Science Ltd.: Amsterdam, The Netherlands, 1979; Volume 2.

53. Zhang, B.; Zhang, G.; Wang, Q.; Li, C.; He, J.; An, Z. Suppression of surface charge accumulation on $\mathrm{Al}_{2} \mathrm{O}_{3}$-filled epoxy resin insulator under dc voltage by direct fluorination. AIP Adv. 2015, 5, 127207. [CrossRef]

54. Bhattacharya, M. Polymer Nanocomposites-A Comparison between Carbon Nanotubes, Graphene, and Clay as Nanofillers. Materials 2016, 9, 262. [CrossRef] [PubMed]

55. Doganay, D.; Coskun, S.; Kaynak, C.; Unalan, H.E. Electrical, mechanical and thermal properties of aligned silver nanowire/polylactide nanocomposite films. Compos. Part B 2016, 99, 288-296. [CrossRef]

(C) 2018 by the authors. Licensee MDPI, Basel, Switzerland. This article is an open access article distributed under the terms and conditions of the Creative Commons Attribution (CC BY) license (http:/ / creativecommons.org/licenses/by/4.0/). 